Cite this: Dalton Trans., 2014, 43 8446

Received 15th January 2014,

Accepted 21st March 2014

DOI: $10.1039 / c 4 d t 00154 k$

www.rsc.org/dalton

\section{Multiple coupling of silanes with imido complexes of Mo†}

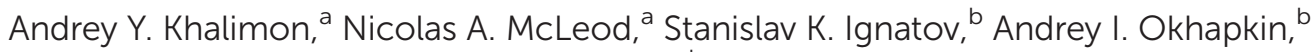 \\ Lyudmila G. Kuzmina, ${ }^{c}$ Judith A. K. Howard ${ }^{d}$ and Georgii I. Nikonov*a
}

\section{Introduction}

Metal mediated transformations of silanes are important in the context of hydrosilylation reactions, ${ }^{1}$ silane aminolysis and alcoholysis, ${ }^{2}$ and C-C coupling reactions of silicates. ${ }^{3}$ In most cases metal complexes can add only one equivalent of silane to give the silyl or silane products and intermediates, but addition of two equivalents of silane is also well documented. ${ }^{4}$ In contrast, only very few examples of multiple addition of silanes are known. ${ }^{5-9}$ These include the preparation of tris(silyl) complexes of $\mathrm{Pt}^{5,6}$ and $\mathrm{Ni}^{7}$ a bis(silyl) bis(disilane) $\sigma$-complex of Pd, ${ }^{8}$ and a tetra(silane) complex of Ti. ${ }^{9}$

We have previously reported couplings of silanes with imido complexes of Mo to give $\beta$-agostic silylamido complexes $^{10}$ and more recently reported a double silane addition to the bis(arylimido) complex $(\mathrm{ArN}=)_{2} \mathrm{Mo}\left(\mathrm{PMe}_{3}\right)_{3}$ to give the agostic silylamido silyl complex $(\mathrm{ArN}=)\left(\eta^{3}-\mathrm{ArNSiPhH}-\mathrm{H}\right) \mathrm{Mo}-$ $\left(\mathrm{PMe}_{3}\right)\left(\mathrm{SiH}_{2} \mathrm{Ph}\right) .{ }^{11}$ Reactions of the latter compound with unsaturated substrates showed the possibility of multicomponent silane additions to organic molecules; ${ }^{12}$ however, making such interesting transformations in a catalytic fashion requires the detachment of the transformed imido moiety from the metal

${ }^{a}$ Chemistry Department, Brock University, 500 Glenridge Ave., St. Catharines, ON L2S 3A1, Canada. E-mail: gnikonov@brocku.ca; Fax: +1 (905)6829020; Tel: +1 (905) 6885550, ext 3350

${ }^{b}$ Chemistry Department, N. I. Lobachevsky State University of Nizhny Novgorod, Gagarin Avenue 23, 603950 Nizhny Novgorod, Russia. E-mail: skignatov@gmail.com ${ }^{c}$ N. S. Kurnakov Institute of General and Inorganic Chemistry, 31 Leninskii prospect, Moscow, 119991, Russia

${ }^{d}$ Department of Chemistry, University of Durham, South Road, Durham, DH1 3LE, $U K$

$\dagger$ Electronic supplementary information (ESI) available: Complete experimental and computational details. CCDC 981174. For ESI and crystallographic data in CIF or other electronic format see DOI: $10.1039 / \mathrm{c} 4 \mathrm{dt} 00154 \mathrm{k}$ at some step. Here we report a triple silane addition to the bis(alkylimido) complex $\left({ }^{t} \mathrm{BuN}=\right)_{2} \mathrm{Mo}\left(\mathrm{PMe}_{3}\right)_{2}$ which results in the ultimate disconnection of one of the imido ligands from the metal. Mechanistic studies further revealed the intermediacy of rare $\gamma$-Si-H agostic ${ }^{13,14}$ and silanimine $e^{12,15}$ complexes.

\section{Results and discussion}

Room temperature reactions of the bis(imido) complexes $\left({ }^{t} \mathrm{BuN}=\right)_{2} \mathrm{Mo}(\mathrm{L})\left(\mathrm{PMe}_{3}\right)\left(\mathrm{L}=\mathrm{PMe}_{3}(\mathbf{1}), \eta^{2}-\mathrm{CH}_{2}=\mathrm{CH}_{2}\right.$ (2)) with 3 equivalents of $\mathrm{PhSiH}_{3}$ afford the compound $\left({ }^{t} \mathrm{BuN}\right)\left\{\mu{ }^{-}{ }^{t} \mathrm{BuN}-\right.$ $\left.(\mathrm{SiHPh})_{2}\right\} \mathrm{Mo}(\mathrm{H})\left(\mathrm{SiH}_{2} \mathrm{Ph}\right)\left(\mathrm{PMe}_{3}\right)_{2}(3)$ in $82 \%$ isolated yield after crystallization at $-30{ }^{\circ} \mathrm{C}$ (Scheme 1). Complex 3 was character-
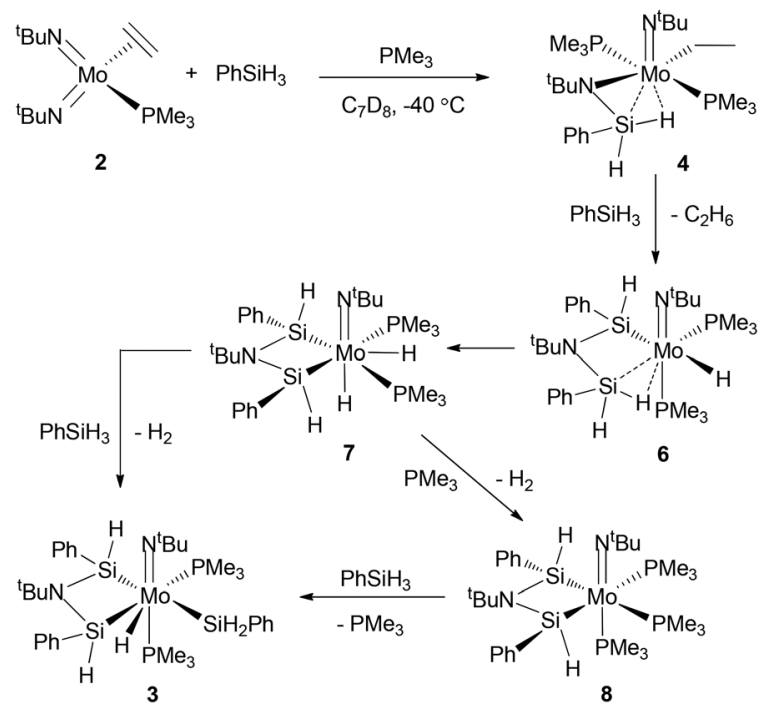

Scheme 1 Intermediates observed en route to complex 3. 


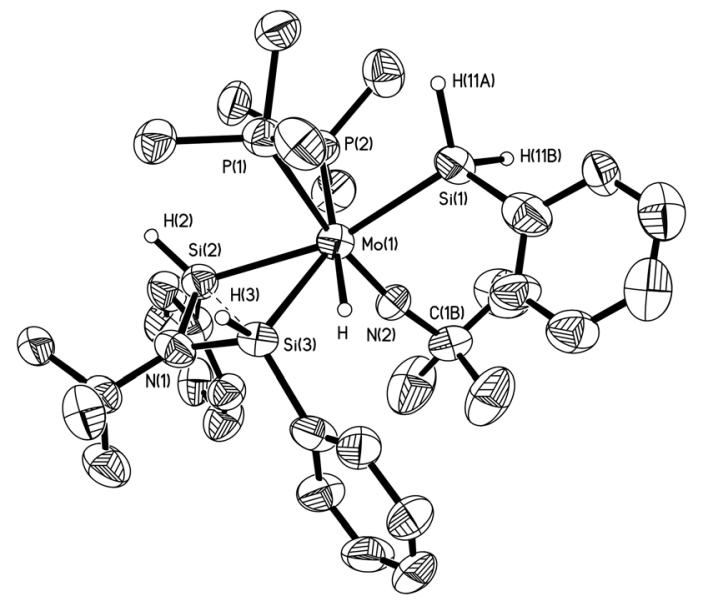

Fig. 1 Molecular structure of complex 3. Thermal ellipsoids are plotted at the $50 \%$ probability level. Hydrogen atoms, apart from hydrides, are omitted for clarity. Selected bonds (Å) and angles ( $\left(^{\circ}\right)$ : Mo1-N2 1.723(8), Mo1-P1 2.685(3), Mo1-P2 2.522(4), Mo1-Si1 2.571(3), Mo1-Si2 2.615(3), Mo1-Si3 2.560(3), N2-Mo1-Si1 90.6(3), N2-Mo1-Si2 104.3(3), N2Mo1-Si3 100.2(3), N2-Mo1-P1 167.8(3), N2-Mo1-P2 98.6(3), P2-Mo1Si1 88.85(11), P2-Mo1-Si2 83.49(10), Si1-Mo1-Si2 164.09(11), Si3Mo1-Si1 122.63(11), Si3-Mo1-Si2 60.85(10), P2-Mo1-P1 87.43(11), Si3Mo1-P1 80.81(10), Si1-Mo1-P1 78.77(10), Si2-Mo1-P1 86.94(10), Si3N1-Si2 98.1(4).

ized by IR, multinuclear NMR, and X-ray diffraction study (Fig. 1). The ${ }^{1} \mathrm{H}$-NMR spectrum of 3 at $-28{ }^{\circ} \mathrm{C}$ shows four $\mathrm{SiH}$ signals of equal intensity: at $5.13 \mathrm{ppm}\left(\mathrm{bd},{ }^{3} J_{\mathrm{H}-\mathrm{P}}=19.6 \mathrm{~Hz}\right)$ and $5.60 \mathrm{ppm}\left(\mathrm{dd},{ }^{3} J_{\mathrm{H}-\mathrm{P}}=14.9 \mathrm{~Hz},{ }^{2} J_{\mathrm{H}-\mathrm{H}}=7.5 \mathrm{~Hz}\right)$ for the $\mathrm{SiH}_{2} \mathrm{Ph}$ group and at $6.03 \mathrm{ppm}\left(\mathrm{dd},{ }^{3} \mathrm{~J}_{\mathrm{H}-\mathrm{P}}=9.6,3.7 \mathrm{~Hz}\right)$ and $6.67 \mathrm{ppm}\left(\mathrm{ddd},{ }^{2} J_{\mathrm{H}-\mathrm{H}}=5.9 \mathrm{~Hz},{ }^{3} J_{\mathrm{H}-\mathrm{P}}=11.6,17.2 \mathrm{~Hz}\right.$ ) for the $\left\{(\mathrm{SiHPh})_{2}\left(\mu-\mathrm{N}^{t} \mathrm{Bu}\right)\right\}$ ligand. The Mo-bound hydride gives rise to $\mathrm{a}^{31} \mathrm{P}$-coupled signal at $1.54 \mathrm{ppm}\left(\mathrm{d},{ }^{2} J_{\mathrm{H}-\mathrm{P}}=21.0 \mathrm{~Hz}\right)$. The formulation of complex 3 as a classical tris(silyl) hydride species is supported by the observation of large values of the ${ }^{1} J_{\mathrm{Si}-\mathrm{H}}$ coupling constants $(154.5,186.0$, and $166.9 \mathrm{~Hz})$ for all three silicon signals in the ${ }^{29} \mathrm{Si}$ INEPT + NMR spectrum at -14.3 , -5.0 , and $1.4 \mathrm{ppm}$, respectively, and the absence of any significant $\mathrm{Si}-\mathrm{H}$ coupling to the Mo-bound hydride. ${ }^{16}$ Furthermore, the ${ }^{29} \mathrm{Si}$ INEPT experiment at $-18{ }^{\circ} \mathrm{C}$ shows the presence of only one Si-bound proton on each silicon centre of the $\left\{(\mathrm{SiHPh})_{2}\left(\mu-\mathrm{N}^{t} \mathrm{Bu}\right)\right\}$ ligand, whereas large values of the ${ }^{2} J_{\mathrm{Si}-\mathrm{P}}$ coupling constants $(25.0$ and $20.3 \mathrm{~Hz})$ for the $\left\{(\mathrm{SiHPh})_{2}\left(\mu-\mathrm{N}^{t} \mathrm{Bu}\right)\right\}$ fragment suggest the presence of direct bonding between the silicon atoms and Mo. Altogether, these spectroscopic features provide evidence for the presence of a tris(silyl) hydride complex in the unusually high oxidation state $\mathrm{Mo}(\mathrm{vI})$. The only other precedents for $\mathrm{Mo}(\mathrm{VI})$ silylhydrides are the observation of transient species $\mathrm{Cp}(\mathrm{ArN}=) \mathrm{Mo}\left(\mathrm{SiH}_{2} \mathrm{Ph}\right)_{2} \mathrm{H}^{17}$ and $(\mathrm{ArN}=)$ $\mathrm{Mo}\left(\mathrm{PMe}_{3}\right)_{2}\left(\mathrm{SiH}_{2} \mathrm{Ph}\right)_{2} \mathrm{H}_{2} \cdot{ }^{18}$

The molecular structure of 3 (Fig. 1) can be described as an edge-capped octahedron. The hydride atom is located trans to the phosphine $\mathrm{P}(2)$ whereas the other phosphine $\mathrm{P}(1)$ is trans to the imido group. The $\mathrm{Si}(2)$ atom of the imido-bis(silyl) ligand $\left\{\mu-{ }^{t} \mathrm{BuN}(\mathrm{SiHPh})_{2}\right\}$ occupies the coordination site trans to the silyl $\mathrm{SiH}_{2} \mathrm{Ph}$ (the $\mathrm{Si}(2)-\mathrm{Mo}-\mathrm{Si}(1)$ angle is $164.1^{\circ}$ ), whereas the $\mathrm{Si}(3)$ atom sits on the $\mathrm{Si}(2)$-hydride edge $2.14 \AA$ away from the molybdenum-bound hydride, suggesting the absence of any significant $\mathrm{Si}-\mathrm{H}$ bonding and indicating that the molybdenum atom is in the oxidation state $\mathrm{Mo}(\mathrm{vI})$. This conclusion agrees well with the spectroscopic data in solution and is further supported by other structural data. ${ }^{19}$ Thus, the Mo-Si(3) distance of 2.560(3) $\AA$ is much shorter than the $\mathrm{Mo}-\mathrm{Si}(2)$ bond of 2.615(3) $\AA$ and is actually very close to the single Mo$\mathrm{SiH}_{2} \mathrm{Ph}$ bond of 2.571(3) $\AA$. In contrast, in silane $\sigma$-complexes and $\mathrm{Si}-\mathrm{H}$ agostic compounds, elongated $\mathrm{M}-\mathrm{Si}$ bonds are observed. ${ }^{4,14}$ The Mo-silyl bonds in 3 compare well with the Mo-Si distance of 2.569(3) $\AA$ in the silyl hydride ( $\mathrm{ArN}=)$ Mo$\left(\mathrm{PMe}_{3}\right)_{2}\left(\mathrm{SiH}_{2} \mathrm{Ph}\right)(\mathrm{H})^{18}$ and with the Mo-Si bonds (2.550(2)$2.566(2) \AA)$ in the related complex $\mathrm{Cp}_{2} \mathrm{Mo}\left(\mathrm{SiMe}_{2}\right)_{2}(\mu-\mathrm{S}) .{ }^{20}$ The $\mathrm{Si}(2)-\mathrm{Si}(3)$ distance of 2.621(5) in 3 is relatively short and is actually close to the upper end of Si-Si $\sigma$-bonds (2.33-2.70 ̊), which may suggest the occurrence of some $\mathrm{Si} \cdots \mathrm{Si}$ interactions. ${ }^{21} \mathrm{~A}$ similar feature is observed in other complexes with the $\left\{\mu-\mathrm{R}^{\prime} \mathrm{N}\left(\mathrm{SiR}_{2}-\right)_{2}\right\}$ ligand. ${ }^{20,22}$

The reaction of 2 with two equiv. of $\mathrm{PhSiH}_{3}$ in the presence of 1 equiv. $\mathrm{PMe}_{3}$ was followed by low temperature NMR. After $2 \mathrm{~h}$ at $-40{ }^{\circ} \mathrm{C}, 80 \%$ of 2 converts to a $1: 1$ mixture of $\left({ }^{t} \mathrm{BuN}\right) \mathrm{Mo}-$ $\left(\eta^{3}-\mathrm{N}^{t} \mathrm{Bu}-\mathrm{SiHPh}-\mathrm{H}\right)\left(\mathrm{PMe}_{3}\right)_{2}(\mathrm{Et}) \quad(4)$ and $\left({ }^{t} \mathrm{BuN}\right) \mathrm{Mo}\left(\eta^{3}-\mathrm{N}^{t} \mathrm{Bu}-\right.$ $\mathrm{SiHPh}-\mathrm{H})\left(\mathrm{PMe}_{3}\right)_{2}\left(\mathrm{SiH}_{2} \mathrm{Ph}\right)(5)$. Complex 4 is likely formed upon $\mathrm{Si}-\mathrm{H}$ bond addition across the $\mathrm{Mo}=\mathrm{N}$ bond of $2^{10-12,23}$ and then undergoes Et/SiH${ }_{2} \mathrm{Ph}$ metathesis with $\mathrm{PhSiH}_{3}$ to give $5 .{ }^{24}$ In the ${ }^{1} \mathrm{H}$ NMR spectrum complex 4 gives rise to broad signals at $5.62 \mathrm{ppm}\left({ }^{1} J_{\mathrm{Si}-\mathrm{H}}=212.0 \mathrm{~Hz}\right)$ and $-0.85 \mathrm{ppm}\left({ }^{1} J_{\mathrm{Si}-\mathrm{H}}=125.1\right.$ $\mathrm{Hz}$ ) for the classical and agostic $\mathrm{SiH}$, respectively. The latter coupling constant is comparable with the range of ${ }^{1} J_{\mathrm{Si}-\mathrm{H}}$ found for other agostic $\mathrm{d}^{2}$ silylamide complexes. ${ }^{14}$ Both Si-H resonances are coupled in ${ }^{1} \mathrm{H}^{29} \mathrm{Si} \mathrm{HSQC}$ to the $\mathrm{Si}$ signal at $-74.5 \mathrm{ppm}$. The diastereotopic $\mathrm{CH}_{2}$ protons of the Et group give rise to multiplets at 2.61 and $2.49 \mathrm{ppm}$ coupled to a triplet at $1.96 \mathrm{ppm}\left({ }^{3} J_{\mathrm{H}-\mathrm{H}}=7.53 \mathrm{~Hz}\right)$. Two nonequivalent phosphines in 4 are in the trans arrangement indicated by the large ${ }^{2} J_{\mathrm{P}-\mathrm{P}}$ of $291.8 \mathrm{~Hz}$. The other product, complex 5, is highly fluxional at $-40{ }^{\circ} \mathrm{C}$, but lowering the temperature to $-80^{\circ} \mathrm{C}$ reveals two singlets at 5.78 and $5.83 \mathrm{ppm}$ for the $\mathrm{SiH}_{2} \mathrm{Ph}$ group coupled in ${ }^{1} \mathrm{H}^{29} \mathrm{Si} \mathrm{HSQC}$ to a resonance at $-8.4 \mathrm{ppm}$. The protons from the agostic silyl group are coupled to an upfield ${ }^{29} \mathrm{Si}$ resonance at $-81.1 \mathrm{ppm}$ with ${ }^{1} \mathrm{JSi}_{\mathrm{Si}}=226.1 \mathrm{~Hz}$ and $110.3 \mathrm{~Hz}$. The latter coupling constant corresponds to the agostic $\mathrm{Si}-\mathrm{H} \cdots$ Mo bond. Similarly to complex $\mathbf{4}$, the ${ }^{31} \mathrm{P}$ NMR spectrum of $\mathbf{5}$ shows two doublets with a large ${ }^{2} J_{\mathrm{P}-\mathrm{P}}$ of $268 \mathrm{~Hz}$ indicating two trans phosphines. A 1D EXSY experiment revealed an exchange at $-80{ }^{\circ} \mathrm{C}$ between the Si-H protons of the silylamido ligand of $\mathbf{5}$, but no exchange with the $\mathrm{Mo}-\mathrm{SiH}_{2} \mathrm{Ph}$ group or with free $\mathrm{PhSiH}_{3}$. An equivalent of free ethane is seen in the ${ }^{1} \mathrm{H}-\mathrm{NMR}(\delta=$ $0.92 \mathrm{ppm}$ ), suggesting that complex 5 may be formed via a metathesis between the ethyl group of 4 and free $\mathrm{PhSiH}_{3}$ to generate the silyl ligand.

Warming a mixture of $\mathbf{4}$ and $\mathbf{5}$ to $0{ }^{\circ} \mathrm{C}$ results in complete conversion into the $\gamma$-agostic complex $\left({ }^{t} \mathrm{BuN}=\right) \mathrm{Mo}(\mathrm{H})\left(\eta^{3}\right.$ $\left.\mathrm{PhHSi}-\mathrm{N}\left({ }^{t} \mathrm{Bu}\right)-\mathrm{SiHPh}-\mathrm{H}\right)\left(\mathrm{PMe}_{3}\right)_{2}(\mathbf{6}$, Scheme 1) and production 
of a noticeable amount of free $\mathrm{H}_{2}(\delta=4.57 \mathrm{ppm})$. The formation of 6 presents the first case of a double silane addition to a metal-imido bond and a rare example of a $\gamma$-agostic $\mathrm{SiH}$ complex. ${ }^{13,14}$ Compound 6 forms as a mixture of two isomers. At $-30{ }^{\circ} \mathrm{C}$ the major isomer exhibits the Mo-H signal at $-4.40 \mathrm{ppm}\left(\mathrm{dd},{ }^{2} J_{\mathrm{H}-\mathrm{P}}=15.8 \mathrm{~Hz}\right.$ and $\left.48.4 \mathrm{~Hz}\right)$ and the $\mathrm{Si}-\mathrm{H}$ resonance for the classical $\mathrm{NSiH}(\mathrm{Ph}) \mathrm{Mo}$ fragment at $6.91 \mathrm{ppm}$, coupled in the ${ }^{1} \mathrm{H}-{ }^{29} \mathrm{Si} H S Q C$ to the ${ }^{29} \mathrm{Si}$ signal at $5.2 \mathrm{ppm}(\mathrm{d}$, ${ }^{1} J_{\mathrm{Si}-\mathrm{H}}=172.3 \mathrm{~Hz}$ ). The terminal proton of the $\mathrm{NSiH}_{2} \mathrm{Ph}$ moiety gives rise to a broad doublet at $6.82 \mathrm{ppm}\left({ }^{2} J_{\mathrm{H}-\mathrm{H}}=5.3 \mathrm{~Hz}\right)$, coupled in the ${ }^{1} \mathrm{H}-{ }^{29} \mathrm{Si}$ HSQC to the ${ }^{29} \mathrm{Si}-\mathrm{NMR}$ signal at $-16.2 \mathrm{ppm}$, whereas the agostic proton gives rise to a broad multiplet at $0.37 \mathrm{ppm}\left(\mathrm{ddd},{ }^{2} J_{\mathrm{H}-\mathrm{P}}=45.5 \mathrm{~Hz},{ }^{2} J_{\mathrm{P}-\mathrm{H}}=4.5 \mathrm{~Hz}\right.$, ${ }^{2} J_{\mathrm{H}-\mathrm{H}}=4.4 \mathrm{~Hz}$ ) coupled to the same ${ }^{29} \mathrm{Si}-\mathrm{NMR}$ signal. In ${ }^{29} \mathrm{Si}$ INEPT+ NMR the agostic silyl signal at $-16.2 \mathrm{ppm}$ comes as a doublet of doublets $\left(\mathrm{dd},{ }^{1} J_{\mathrm{H}-\mathrm{Si}}=34.9 \mathrm{~Hz},{ }^{1} J_{\mathrm{H}-\mathrm{Si}}=195.6 \mathrm{~Hz}\right)$. The significantly reduced coupling $(34.9 \mathrm{~Hz})$ establishes the presence of a $\gamma$-agostic SiH...Mo bond. A NOESY experiment further agrees with the relative disposition of substituents shown in Scheme 1. In particular, the bridging ${ }^{t} \mathrm{BuN}$ group "sees" only the terminal $\mathrm{SiH}$ and $o$-Ph protons, but neither the ${ }^{t} \mathrm{BuN}=\mathrm{Mo}$ nor the phosphine groups, indicating its detachment from the Mo centre.

Addition of another equivalent of $\mathrm{PhSiH}_{3}$ to a freshly generated sample of 6 and warming to $0{ }^{\circ} \mathrm{C}$ leads to the formation of the final product 3 . This may happen either via oxidative addition of the agostic $\mathrm{Si}-\mathrm{H}$ bond to metal affording a $\mathrm{Mo}(\mathrm{vI})$ dihydride species, which after elimination of $\mathrm{H}_{2}$ adds $\mathrm{PhSiH}_{3}$ (pathway A, Scheme 2), or via a $\mathrm{Mo}-\mathrm{H} / \mathrm{Si}-\mathrm{H}$ metathesis with the added silane (pathway B). To distinguish between these two possibilities, a labeling experiment was attempted. Addition of an equivalent of $\mathrm{PhSiD}_{3}$ to 6 led to deuterium scrambling into the $\mathrm{MoH}$ and all $\mathrm{SiH}$ positions. The same result was obtained upon addition of $\mathrm{PhSiD}_{3}$ to 3 . These experiments indicate a reversible behaviour which can be interpreted as reversible addition of silane to a silanimine intermediate and exchange of the agostic $\mathrm{Si}-\mathrm{H}$ bond between both sides of the PhHSi-N $\left({ }^{t} \mathrm{Bu}\right)-\mathrm{SiHPh}$ unit of 6 . The latter exchange can happen by reversible $\mathrm{Si}-\mathrm{H}$ bond oxidative addition/reductive elimination. D-scrambling in 3 can be also
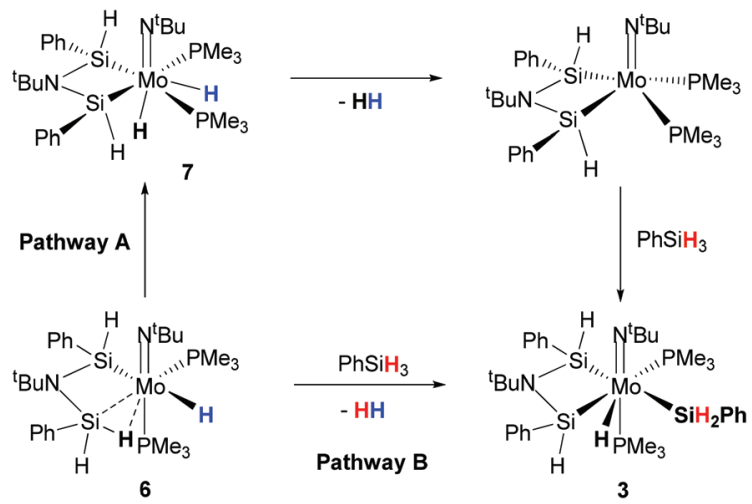

Scheme 2 Possible pathways for the reaction of 6 with $\mathrm{PhSiH}_{3}$. explained by reversible $\mathrm{Si}-\mathrm{H}$ bond formation and cleavage between the silicon atoms of the disilacyclobutane ring and the Mo-bound hydride.

Although the labeling studies do not allow us to distinguish between pathways A and B of Scheme 2, the following experiments suggest that pathway $\mathrm{A}$ (oxidative addition of agostic $\mathrm{Si}-\mathrm{H})$ is realized. When $\left({ }^{t} \mathrm{BuN}\right)_{2} \mathrm{Mo}\left(\mathrm{PMe}_{3}\right)\left(\eta^{2}-\mathrm{C}_{2} \mathrm{H}_{4}\right)$ reacts with 2 equivalents of $\mathrm{PhSiH}_{3}$ in the presence of $\mathrm{PMe}_{3}$ for 3 hours at $-20{ }^{\circ} \mathrm{C}$, a mixture of $6(80 \%), 3(2 \%)$, and a new dihydride complex $\left({ }^{t} \mathrm{BuN}\right) \mathrm{Mo}\left\{(\mathrm{SiHPh})_{2}\left(\mu-\mathrm{N}^{t} \mathrm{Bu}\right)\right\}\left(\mathrm{PMe}_{3}\right)_{2} \mathrm{H}_{2} \quad(7$, $18 \%$ ) is formed. At $0{ }^{\circ} \mathrm{C}, 7$ exhibits two $\mathrm{Si}-\mathrm{H}$ resonances in the ${ }^{1} \mathrm{H}-\mathrm{NMR}$ at $5.92\left({ }^{3} J_{\mathrm{H}-\mathrm{P}}=3.8 \mathrm{~Hz},{ }^{3} J_{\mathrm{H}-\mathrm{P}}=5.9 \mathrm{~Hz},{ }^{3} J_{\mathrm{H}-\mathrm{H}}=\right.$ $11.6 \mathrm{~Hz})$ and $6.51 \mathrm{ppm}\left({ }^{3} J_{\mathrm{H}-\mathrm{H}}=6.1 \mathrm{~Hz},{ }^{3} J_{\mathrm{H}-\mathrm{P}}=6.1 \mathrm{~Hz},{ }^{3} J_{\mathrm{H}-\mathrm{P}}=\right.$ $12.2 \mathrm{~Hz}$ ) correlated to two different ${ }^{29} \mathrm{Si}$ signals in ${ }^{1} \mathrm{H}-{ }^{29} \mathrm{Si}$ HSQC NMR at $4.1 \mathrm{ppm}\left({ }^{1} J_{\mathrm{Si}-\mathrm{H}}=170.0 \mathrm{~Hz}\right)$ and $-2.2 \mathrm{ppm}$ $\left({ }^{1} J_{\mathrm{Si}-\mathrm{H}}=185.3 \mathrm{~Hz}\right)$, respectively. Each $\mathrm{Si}-\mathrm{H}$ signal is coupled to each $\mathrm{PMe}_{3}$ ligand and to a distinct $\mathrm{Mo}-\mathrm{H}$ hydride, confirmed by a $\left.{ }^{1} \mathrm{H}_{\{}^{31} \mathrm{P}\right\}$ experiment. Although the hydride resonances are obscured and could not be observed directly by ${ }^{1} \mathrm{H}-\mathrm{NMR}$, a combination of ${ }^{1} \mathrm{H}-{ }^{1} \mathrm{H}$ COSY, ${ }^{1} \mathrm{H}-{ }^{29} \mathrm{Si} \mathrm{HSQC}$ and ${ }^{1} \mathrm{H}-{ }^{31} \mathrm{P}$ HSQC allowed us to establish their positions at $1.48 \mathrm{ppm}$ (coupled to both ${ }^{29} \mathrm{Si}$ signals at $-2.2 \mathrm{ppm}$ and $4.1 \mathrm{ppm}$ and to the ${ }^{31} \mathrm{P}$ signal at $-9.65 \mathrm{ppm}$ ) and at $1.25 \mathrm{ppm}$ (coupled only to the ${ }^{29} \mathrm{Si}$ resonance at $4.1 \mathrm{ppm}$ and to both ${ }^{31} \mathrm{P}$ signals). These data, however, do not allow us to distinguish between a dihydride $v s$. a stretched dihydrogen description of $7 .^{25}$

In another experiment, keeping a solution of 6 at $-30{ }^{\circ} \mathrm{C}$ for three days produces significant amounts of the imidobridged bis(silyl) complex $\left({ }^{t} \mathrm{BuN}=\right) \mathrm{Mo}\left\{\eta^{2}-\mathrm{N}^{t} \mathrm{Bu}(\mathrm{SiHPh})_{2}\right\}^{-}$ $\left(\mathrm{PMe}_{3}\right)_{3}$ (8, Scheme 1), which most likely forms via oxidative addition of the agostic SiH bond to Mo in 6, dihydrogen elimination and addition of $\mathrm{PMe}_{3}$, which provides further support towards pathway A. The structure of $\mathbf{8}$ was established by multinuclear NMR and NOESY experiments. At $0{ }^{\circ} \mathrm{C}$, complex 8 exhibits two $\mathrm{Si}-\mathrm{H}$ resonances at $5.36 \mathrm{ppm}\left(\mathrm{ddd},{ }^{3} J_{\mathrm{H}-\mathrm{P}}=3.0 \mathrm{~Hz}\right.$, $\left.{ }^{3} J_{\mathrm{H}-\mathrm{P}}=5.0 \mathrm{~Hz},{ }^{3} J_{\mathrm{H}-\mathrm{P}}=7.8 \mathrm{~Hz}\right)$ and $7.05 \mathrm{ppm}\left(\mathrm{bd},{ }^{3} J_{\mathrm{H}-\mathrm{P}}=9 \mathrm{~Hz}\right)$ in the ${ }^{1} \mathrm{H} \mathrm{NMR}$, corresponding to two nonequivalent silyl groups stemming from the different orientation of the $\mathrm{Ph}$ and $\mathrm{H}$ substituents. The signal at $5.36 \mathrm{ppm}$ shows a ${ }^{3} J_{\mathrm{H}-\mathrm{P}}$ coupling to three nonequivalent $\mathrm{PMe}_{3}$ groups. In ${ }^{31} \mathrm{P}$ NMR these phosphines give rise to a triplet at $5.66\left(\mathrm{t},{ }^{2} J_{\mathrm{P}-\mathrm{P}}=22.6 \mathrm{~Hz}, 1 \mathrm{P}\right)$, coming from the $\mathrm{PMe}_{3}$ located trans to the imido group, and two doublet of doublets $\left({ }^{2} J_{\mathrm{P}-\mathrm{P}}=18.2 \mathrm{~Hz}\right.$ and $\left.{ }^{2} J_{\mathrm{P}-\mathrm{P}}=91.2 \mathrm{~Hz}\right)$ for two mutually trans phosphines at -7.48 and $-13.54 \mathrm{ppm}$. The ${ }^{29} \mathrm{Si}$ INEPT+ NMR spectrum revealed two ${ }^{29} \mathrm{Si}$ resonances: a broad doublet at $41.7 \mathrm{ppm}\left({ }^{1} J_{\mathrm{Si}-\mathrm{H}}=169.3 \mathrm{~Hz}\right)$ and a doublet of ${ }^{31} \mathrm{P}$-coupled multiplets at $-10.42 \mathrm{ppm}$ (dddd, Mo-SiHPh, ${ }^{1} J_{\mathrm{Si}-\mathrm{H}}=152.0 \mathrm{~Hz},{ }^{2} J_{\mathrm{Si}-\mathrm{P}}=19.3 \mathrm{~Hz},{ }^{2} J_{\mathrm{Si}-\mathrm{P}}=19.3 \mathrm{~Hz}$, $\left.{ }^{2} J_{\mathrm{Si}-\mathrm{P}}=38.3 \mathrm{~Hz}\right)$. Altogether, these spectroscopic observations provide evidence of a pseudo-octahedral structure having transoid orientation of the $\mathrm{Ph}$ and $\mathrm{H}$ substituents at the silicon centres.

A similar low temperature NMR study for the reaction of the complex $\left({ }^{t} \mathrm{BuN}\right)_{2} \mathrm{Mo}\left(\mathrm{PMe}_{3}\right)_{2}$ (1) with $\mathrm{PhSiH}_{3}$ also revealed the intermediate $\mathbf{6}$ and its conversion to 3 . 
Table 1 DFT calculated energies (in $\mathrm{kcal} \mathrm{mol}^{-1}$ ) for the reaction between 1 and silane $\mathrm{PhSiH}_{3}$ to give complex 3 in gas phase and benzene solution. The energy of the pair $1+\mathrm{H}_{3} \mathrm{SiPh}$ is taken as 0

\begin{tabular}{|c|c|c|}
\hline Structure & Gas phase & Solution \\
\hline 1 & 0 & 0 \\
\hline 3 & -25.3 & -24.0 \\
\hline $\mathrm{TS}_{4 \mathrm{H}}$ & 19.7 & 19.5 \\
\hline $4 \mathrm{Ha}$ & -2.2 & -1.4 \\
\hline $4 \mathrm{Hb}$ & -0.1 & 0.5 \\
\hline $\mathrm{TS}_{49}$ & 15.9 & 16.4 \\
\hline 9 & -0.5 & -0.2 \\
\hline 6 & -21.2 & -20.1 \\
\hline $\mathrm{TS}_{67}$ & -9.1 & -8.3 \\
\hline 7 & -18.9 & -18.4 \\
\hline $\mathbf{T S}_{710}$ & -17.9 & -17.3 \\
\hline 10 & -18.9 & -18.1 \\
\hline 11 & -12.4 & -12.6 \\
\hline
\end{tabular}

The structure and interconversion of various species formed en route to compound 3 were further investigated by DFT calculations of the real system $\left({ }^{t} \mathrm{BuN}=\right)_{2} \mathrm{Mo}\left(\mathrm{PMe}_{3}\right)_{2} /$ $\mathrm{H}_{3} \mathrm{SiPh}$. Solvent effects were taken into account by the polarizable continuum model (PCM). ${ }^{26}$ The data are given in Table 1. Addition of silane to the $\mathrm{Mo}=\mathrm{N}$ bond of $\left({ }^{t} \mathrm{BuN}=\right)_{2} \mathrm{Mo}\left(\mathrm{PMe}_{3}\right)_{2}$ (1) proceeds via the $\operatorname{TS}_{\mathbf{1 4}}\left(\Delta G^{\neq}=34.1 \mathrm{kcal} \mathrm{mol}{ }^{-1}\right)$ and affords the silylamido complex $\mathbf{4 H}$, a hydride analogue of the ethyl complex 4. We found two isomers of this species. The most stable isomer $4 \mathbf{H a}\left(\Delta G_{\mathrm{f}}=12.5 \mathrm{kcal} \mathrm{mol}^{-1}\right)$ has a trigonal
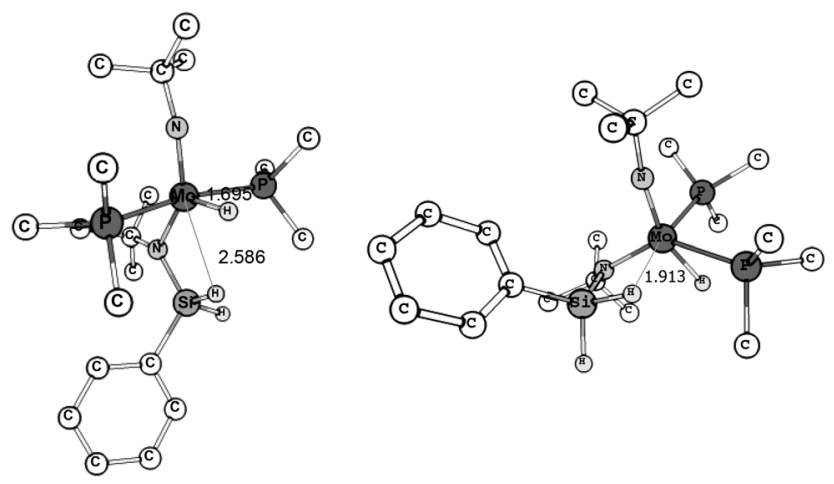

Fig. 2 Calculated isomers of intermediate $4 \mathrm{H}(4 \mathrm{Ha}-$ left; $4 \mathrm{Hb}-$ right).

bipyramidal structure with two trans phosphines and a nonagostic silylamido ligand (the $\mathrm{SiH} \cdots \mathrm{Mo}$ distance is $2.586 \AA$, Fig. 2). The higher energy isomer $\mathbf{4} \mathbf{H b}\left(\Delta G_{\mathrm{f}}=17.2 \mathrm{kcal} \mathrm{mol}^{-1}\right)$ has a pseudo-octahedral structure, with the hydride lying trans to the imido ligand and one of the vertices being occupied by a silicon-bond hydride to form the SiH $\cdots$ Mo distance of $1.913 \AA$. The latter isomer can be classified as a $\beta$-SiH agostic complex. In the next step, elimination of dihydrogen from $\mathbf{4 H}$ takes place via the transition state $\mathbf{T S}_{\mathbf{4 9}}$, lying $31.9 \mathrm{kcal} \mathrm{mol}^{-1}$ above the starting complex $\mathbf{1}$, to give the silanimine intermediate $\mathbf{9}$ (Fig. 3). Formation of $\mathbf{4 H}$ is strongly endergonic, whereas 9 is only marginally (by $1.2 \mathrm{kcal} \mathrm{mol}^{-1}$, which is within the

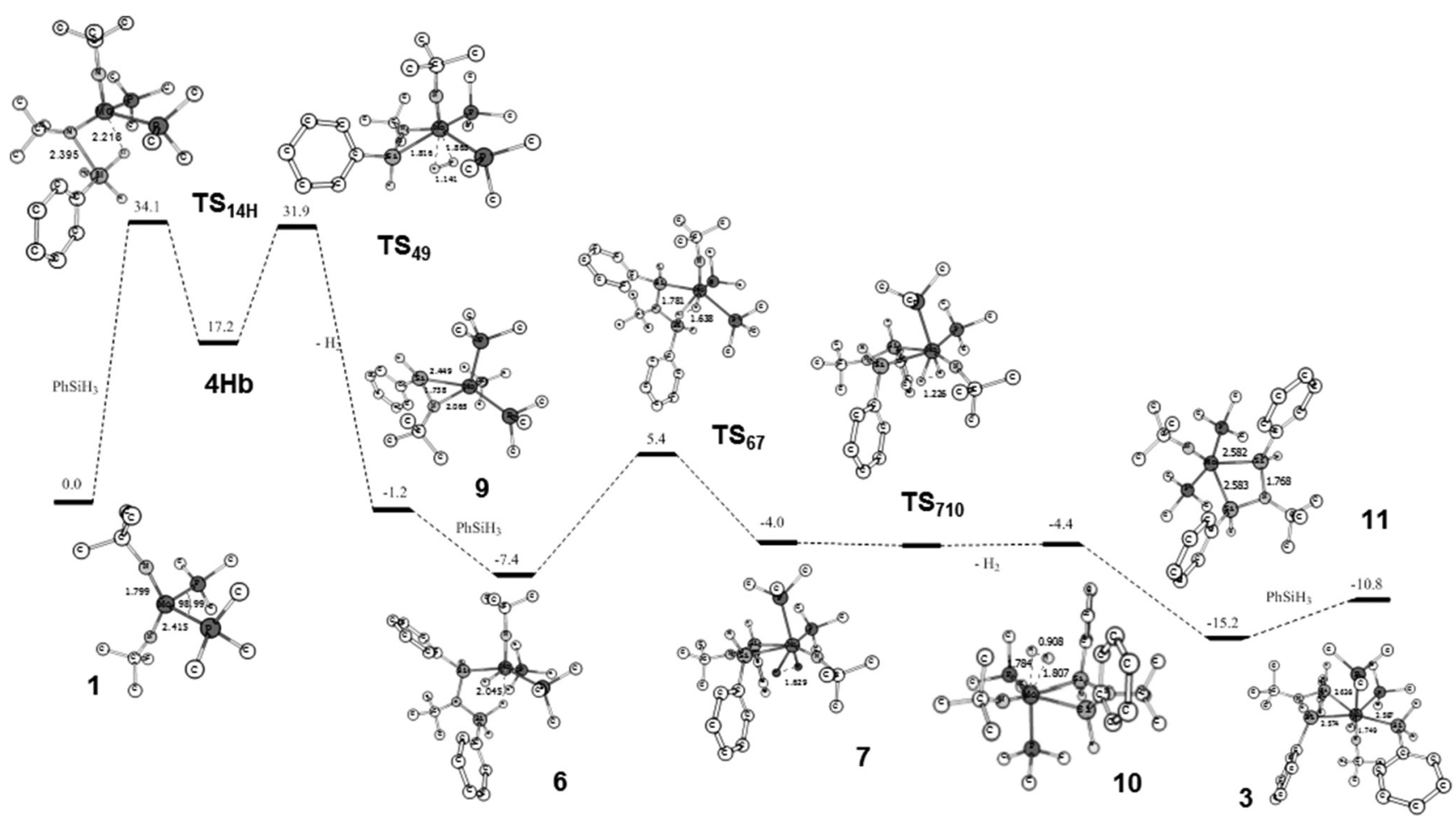

Fig. 3 Mechanism of formation of complex 3. Hydrogen atoms, apart from hydrides on Si and Mo, are omitted for clarity. The Gibbs free energy is given in kcal mol ${ }^{-1}$. The $\mathrm{TS}_{710}$ is just $0.6 \mathrm{kcal} \mathrm{mol}^{-1}$ above 7 on the electronic energy surface but is $1 \mathrm{kcal}^{\text {mol }}{ }^{-1}$ lower on the Gibbs free energy surface. 
error of our calculation) more stable than 1, which explains why both species could not be observed experimentally. Considering the fact that the real complexes $\mathbf{4}$ and $\mathbf{6}$ form reasonably fast even at low temperature $\left(-40{ }^{\circ} \mathrm{C}\right)$, the calculated barriers for the first two steps appear to be too high. This may be in part due to the overestimation of the entropy contribution by our calculations or, more likely, indicate the presence of an alternative but as yet unknown reaction pathway.

Silane addition to 9 across the Mo-N bond of the silanimine ligand affords the $\gamma$-agostic complex $\mathbf{6}$, the first intermediate observed by low temperature NMR for the mixture of $\left({ }^{t} \mathrm{BuN}=\right)_{2} \mathrm{Mo}\left(\mathrm{PMe}_{3}\right)_{2}$ and $\mathrm{H}_{3} \mathrm{SiPh}$. Compound 6 is stabilized relative to the starting compound 1 by $7.4 \mathrm{kcal} \mathrm{mol}^{-1}$. The agostic SiH hydride in 6 is located $2.045 \AA$ away from Mo, trans to the imido ligand and cis to the $\mathrm{Mo}-\mathrm{H}$ bond. Oxidative addition of the $\mathrm{Si}-\mathrm{H}$ bond to Mo generates the dihydride species 7 by overcoming a modest barrier of $12.8 \mathrm{kcal} \mathrm{mol}^{-1}$ $\left(\mathbf{T S}_{\mathbf{6 7}}\right)$. In 7 the distance between the Mo-bound hydrides is $1.628 \AA$, which allows us to classify this species as a cis dihydride complex. ${ }^{25}$ Compound 7 is connected via the transition state $\mathbf{T S}_{\mathbf{7 1 0}}$ with the dihydrogen complex 10 characterized by the short $\mathrm{H} \cdots \mathrm{H}$ distance of $0.908 \AA^{25,27}$ The potential surface around 7 and $\mathbf{1 0}$ is very shallow, so that both species must be in fast equilibrium. 7 and 10 are $\sim 4.0 \mathrm{kcal} \mathrm{mol}^{-1}$ more stable than 1 and together they account for the second observable intermediate. Elimination of dihydrogen affords the imidobridged bis(silyl) complex 11. The experimentally observed compound 8 can be regarded as an adduct of 11 with $\mathrm{PMe}_{3}$. Finally, addition of silane to $\mathbf{1 1}$ to furnish complex $\mathbf{3}$ completes this reaction sequence.

\section{Conclusion}

We have demonstrated an unusual triple silane addition to the bis(imido) complexes of Mo 1 and 2 which proceeds via a series of $\mathrm{Si}-\mathrm{H}$ agostic and silanimine intermediates and results in complete detachment of one of the imido ligands from Mo. Studies are underway to probe the relevance of these species to catalytic coupling of $\mathrm{PhSiH}_{3}$ with unsaturated organic molecules.

\section{Experimental}

All manipulations were carried out using conventional inert atmosphere glove-box and Schlenk techniques. Dry diethyl ether, toluene, hexanes, and acetonitrile were obtained, using Grubbs-type purification columns, and other solvents were dried by distillation from appropriate drying agents. NMR spectra were obtained with a Bruker DPX-300 and a Bruker DPX-600 instrument $\left({ }^{1} \mathrm{H}\right.$ : 300 and $600 \mathrm{MHz} ;{ }^{13} \mathrm{C}: 75.5$ and $151 \mathrm{MHz} ;{ }^{29} \mathrm{Si}: 59.6$ and $119.2 \mathrm{MHz} ;{ }^{31} \mathrm{P}: 121.5$ and $243 \mathrm{MHz}$ ). NMR spectra were taken at room temperature unless specified otherwise. IR spectra were measured on a Perkin-Elmer 1600 FT-IR spectrometer. Elemental analyses were performed in
"ANALEST" laboratories (University of Toronto). Preparation of $\left({ }^{t} \mathrm{BuN}=\right)_{2} \mathrm{Mo}\left(\mathrm{PMe}_{3}\right)_{2}(\mathbf{1})^{10 a, 28}$ and $\left({ }^{t} \mathrm{BuN}=\right)_{2} \mathrm{Mo}\left(\mathrm{PMe}_{3}\right)\left(\eta^{2}-\mathrm{C}_{2} \mathrm{H}_{4}\right)$ $(2)^{29}$ was reported previously. $\mathrm{PhSiH}_{3}$ and $\mathrm{PhSiD}_{3}$ were prepared from $\mathrm{PhSiCl}_{3}$ by treatment with $\mathrm{LiAlH}_{4}$ or $\mathrm{LiAlD}_{4}$, respectively. Mechanistic studies were carried out under a nitrogen atmosphere using NMR tubes equipped with Teflon valves.

\section{Synthesis of $\left({ }^{t} \mathrm{BuN}\right)\left\{\mu-{ }^{t} \mathrm{BuN}(\mathrm{SiHPh})_{2}\right\} \mathrm{Mo}(\mathrm{H})\left(\mathrm{SiH}_{2} \mathrm{Ph}\right)\left(\mathrm{PMe}_{3}\right)_{2}(3)$}

A solution of $1(0.30 \mathrm{~g}, 0.769 \mathrm{mmol})$ in hexanes $(12 \mathrm{~mL})$ was precooled to $-30{ }^{\circ} \mathrm{C}$ using an acetone $/ \mathrm{CO}_{2}$ bath. $\mathrm{PhSiH}_{3}$ $(0.19 \mathrm{~mL}, 1.54)$ was added in one portion and the mixture was stirred for $1 \mathrm{~h} 20 \mathrm{~min}$ at $-30^{\circ} \mathrm{C}$. After this time period the solution was warmed to $-5{ }^{\circ} \mathrm{C}$ and all volatiles removed under vacuum to give a light brown powder (0.38 g, 82\%). Alternatively, a similar procedure using complex 2 with one equivalent of $\mathrm{PMe}_{3}$ in a hexane-toluene $(5: 1)$ mixture can be employed, resulting in similar yields and purity. ${ }^{1} \mathrm{H}-\mathrm{NMR}(600 \mathrm{MHz}$; toluene- $\left.\mathrm{d}_{8} ;-28{ }^{\circ} \mathrm{C} ; \delta, \mathrm{ppm}\right): 0.62\left(\mathrm{~s}, 9 \mathrm{H},{ }^{t} \mathrm{BuN}\right), 0.99\left(\mathrm{~d},{ }^{2} J_{\mathrm{P}-\mathrm{H}}=\right.$ $\left.6.0 \mathrm{~Hz}, 9 \mathrm{H}, \mathrm{PMe} e_{3}\right), 1.04\left(\mathrm{~d},{ }^{2} J_{\mathrm{P}-\mathrm{H}}=7.5 \mathrm{~Hz}, 9 \mathrm{H}, \mathrm{PMe} e_{3}\right), 1.47(\mathrm{~s}$, $9 \mathrm{H},{ }^{t} \mathrm{BuN}$ ), $1.54\left(\mathrm{bd}, 1 \mathrm{H},{ }^{2} J_{\mathrm{P}-\mathrm{H}}=21.0 \mathrm{~Hz}, \mathrm{MoH}\right), 5.13(\mathrm{bd}, 1 \mathrm{H}$, $\left.{ }^{2} J_{\mathrm{P}-\mathrm{H}}=19.6 \mathrm{~Hz}, \mathrm{SiH} H_{2} \mathrm{Ph}\right), 5.60\left(\mathrm{dd}, 1 \mathrm{H},{ }^{3} J_{\mathrm{P}-\mathrm{H}}=14.9 \mathrm{~Hz},{ }^{2} J_{\mathrm{H}-\mathrm{H}}=\right.$ $7.5 \mathrm{~Hz}, \mathrm{Si} \mathrm{H}_{2} \mathrm{Ph}$ ), $6.03\left(\mathrm{dd}, 1 \mathrm{H},{ }^{3} \mathrm{~J}_{\mathrm{P}-\mathrm{H}}=9.6 \mathrm{~Hz},{ }^{3} J_{\mathrm{P}-\mathrm{H}}=3.7 \mathrm{~Hz}\right.$, $\left.\left\{(\mathrm{Si} H \mathrm{Ph})_{2}\left(\mu-\mathrm{N}^{t} \mathrm{Bu}\right)\right\}\right), 6.67\left(\mathrm{ddd}, 1 \mathrm{H},{ }^{2} J_{\mathrm{H}-\mathrm{H}}=5.9 \mathrm{~Hz},{ }^{3} J_{\mathrm{P}-\mathrm{H}}=11.6\right.$ $\left.\mathrm{Hz},{ }^{3} J_{\mathrm{P}-\mathrm{H}}=17.2 \mathrm{~Hz},\left\{(\mathrm{SiHPh})_{2}\left(\mu-\mathrm{N}^{t} \mathrm{Bu}\right)\right\}\right), 7.26(\mathrm{~m}, 2 \mathrm{H}, p-\mathrm{H}$, $\mathrm{Si} P h), 7.32\left(\mathrm{t}, 1 \mathrm{H},{ }^{3} J_{\mathrm{H}-\mathrm{H}}=7.5 \mathrm{~Hz}, p-\mathrm{H}, \mathrm{Si} P h\right), 7.40\left(\mathrm{t}, 2 \mathrm{H},{ }^{3} J_{\mathrm{H}-\mathrm{H}}=\right.$ $7.5 \mathrm{~Hz}, m-\mathrm{H}, \mathrm{Si} P h), 7.46\left(\mathrm{t}, 2 \mathrm{H},{ }^{3} J_{\mathrm{H}-\mathrm{H}}=7.5 \mathrm{~Hz}, m-\mathrm{H}, \mathrm{Si} P h\right), 7.49$ $\left(\mathrm{t}, 2 \mathrm{H},{ }^{3} J_{\mathrm{H}-\mathrm{H}}=7.5 \mathrm{~Hz}, m-\mathrm{H}, \mathrm{Si} P h\right), 8.32$ (bs, $\left.2 \mathrm{H}, o-\mathrm{H}, \mathrm{Si} P h\right), 8.48$ $\left(\mathrm{d}, 2 \mathrm{H},{ }^{3} J_{\mathrm{H}-\mathrm{H}}=6.6 \mathrm{~Hz}, o-\mathrm{H}, \mathrm{Si} P h\right), 8.54\left(\mathrm{~d}, 2 \mathrm{H},{ }^{3} J_{\mathrm{H}-\mathrm{H}}=6.7 \mathrm{~Hz}\right.$, $o$-H, SiPh). ${ }^{1} \mathrm{H}$-NMR (600 MHz; toluene- $\left.\mathrm{d}_{8} ; 22{ }^{\circ} \mathrm{C} ; \delta, \mathrm{ppm}\right): 0.61$ $\left(\mathrm{s}, 9 \mathrm{H},{ }^{t} \mathrm{BuN}\right), 1.05\left(\mathrm{~d},{ }^{2} J_{\mathrm{P}-\mathrm{H}}=6.4 \mathrm{~Hz}, \mathrm{PMe} e_{3}\right), 1.14\left(\mathrm{~d}, 9 \mathrm{H},{ }^{2} J_{\mathrm{P}-\mathrm{H}}=\right.$ $7.7 \mathrm{~Hz}, \mathrm{PMe} e_{3}$ ), $1.39\left(\mathrm{~s}, 9 \mathrm{H},{ }^{t} \mathrm{BuN}\right), 1.50\left(\mathrm{bd}, 1 \mathrm{H},{ }^{2} J_{\mathrm{P}-\mathrm{H}}=21.0 \mathrm{~Hz}\right.$, $\mathrm{MoH}$ ), 5.05 (d, $1 \mathrm{H},{ }^{3} J_{\mathrm{P}-\mathrm{H}}=19.4 \mathrm{~Hz}, \mathrm{Si} H_{2} \mathrm{Ph}$ ), 5.50 (bddd, $1 \mathrm{H}$, $\left.{ }^{3} J_{\mathrm{P}-\mathrm{H}}=15.9 \mathrm{~Hz},{ }^{2} J_{\mathrm{H}-\mathrm{H}}=7.4 \mathrm{~Hz}, \mathrm{Si} H_{2} \mathrm{Ph}\right), 6.04\left(\mathrm{dd}, 1 \mathrm{H},{ }^{3} J_{\mathrm{P}-\mathrm{H}}=\right.$ $\left.3.7 \mathrm{~Hz},{ }^{3} J_{\mathrm{P}-\mathrm{H}}=9.2 \mathrm{~Hz},\left\{(\mathrm{SiHPh})_{2}\left(\mu-\mathrm{N}^{t} \mathrm{Bu}\right)\right\}\right), 6.59\left(\mathrm{ddd}, 1 \mathrm{H},{ }^{2} J_{\mathrm{H}-\mathrm{H}}\right.$ $\left.=5.8 \mathrm{~Hz},{ }^{3} J_{\mathrm{P}-\mathrm{H}}=11.6 \mathrm{~Hz},{ }^{3} J_{\mathrm{P}-\mathrm{H}}=17.5 \mathrm{~Hz},\left\{(\mathrm{SiHPh})_{2}\left(\mu-\mathrm{N}^{t} \mathrm{Bu}\right)\right\}\right)$, $7.23(\mathrm{~m}, 3 \mathrm{H}, p-\mathrm{H}, \mathrm{Si} P h), 7.36\left(\mathrm{t}, 2 \mathrm{H},{ }^{3} J_{\mathrm{H}-\mathrm{H}}=7.3 \mathrm{~Hz}, m-\mathrm{H}, \mathrm{Si} P h\right)$, $7.40\left(\mathrm{t}, 4 \mathrm{H},{ }^{3} \mathrm{~J}_{\mathrm{H}-\mathrm{H}}=7.0 \mathrm{~Hz}, m-\mathrm{H}, \mathrm{Si} P h\right), 8.25\left(\mathrm{~d}, 2 \mathrm{H},{ }^{3} J_{\mathrm{H}-\mathrm{H}}=7.0\right.$ $\mathrm{Hz}, o-\mathrm{H}, \mathrm{Si} P h), 8.37\left(\mathrm{~d}, 2 \mathrm{H},{ }^{3} J_{\mathrm{H}-\mathrm{H}}=7.3 \mathrm{~Hz}, o-\mathrm{H}, \mathrm{Si} P h\right), 8.39(\mathrm{~d}$, $\left.2 \mathrm{H},{ }^{3} J_{\mathrm{H}-\mathrm{H}}=7.3 \mathrm{~Hz}, o-\mathrm{H}, \quad \mathrm{Si} P h\right) .{ }^{1} \mathrm{H}\left\{{ }^{31} \mathrm{P}\right\}-\mathrm{NMR}(600 \mathrm{MHz}$, toluene- $d_{8}, 22{ }^{\circ} \mathrm{C}, \delta$, ppm, selected resonances): 6.59 (d, $\left.1 \mathrm{H},{ }^{2} J_{\mathrm{H}-\mathrm{H}}=5.9 \mathrm{~Hz},\left\{(\mathrm{SiHPh})_{2}\left(\mu-\mathrm{N}^{t} \mathrm{Bu}\right)\right\}\right), 6.04 \quad(\mathrm{~s}, \quad 1 \mathrm{H}$, $\left.\left\{(\mathrm{Si} H \mathrm{Ph})_{2}\left(\mu-\mathrm{N}^{t} \mathrm{Bu}\right)\right\}\right), 5.49\left(\mathrm{~s}, 1 \mathrm{H}, \mathrm{Si} H_{2} \mathrm{Ph}\right), 5.05$ (s, $\left.1 \mathrm{H}, \mathrm{Si} H_{2} \mathrm{Ph}\right)$, $1.55\left(\mathrm{~d}, 1 \mathrm{H},{ }^{2} J_{\mathrm{H}-\mathrm{H}}=5.9 \mathrm{~Hz}, \mathrm{MoH}\right) .{ }^{31} \mathrm{P}\left\{{ }^{1} \mathrm{H}\right\}-\mathrm{NMR}(243.0 \mathrm{MHz}$, toluene- $d_{8},-28{ }^{\circ} \mathrm{C}, \delta$, ppm): $-40.2\left(\mathrm{~d},{ }^{2} J_{\mathrm{P}-\mathrm{P}}=34.5 \mathrm{~Hz}, P \mathrm{Me}_{3}\right.$ ), $-16.3\left(\mathrm{~d},{ }^{2} J_{\mathrm{P}-\mathrm{P}}=34.5 \mathrm{~Hz}, P \mathrm{Me}_{3}\right) .{ }^{31} \mathrm{P}\left\{{ }^{1} \mathrm{H}\right\}-\mathrm{NMR}(121.5 \mathrm{MHz}$, toluene- $\left.d_{8}, 22{ }^{\circ} \mathrm{C}, \delta, \mathrm{ppm}\right):-41.5\left(\mathrm{~d},{ }^{2} J_{\mathrm{P}-\mathrm{P}}=32.0 \mathrm{~Hz}, P \mathrm{Me}_{3}\right)$, $-17.2\left(\mathrm{~d},{ }^{2} J_{\mathrm{P}-\mathrm{P}}=34.5 \mathrm{~Hz}, P \mathrm{Me}_{3}\right) .{ }^{29} \mathrm{Si}$ INEPT+ NMR (119.2 MHz, toluene- $\left.d_{8},-28{ }^{\circ} \mathrm{C}, J=180 \mathrm{~Hz}, \delta, \mathrm{ppm}\right):-14.3\left(\mathrm{tdd},{ }^{1} J_{\mathrm{Si}-\mathrm{H}}=\right.$ $\left.154.4 \mathrm{~Hz},{ }^{2} J_{\mathrm{Si}-\mathrm{P}}=25.0 \mathrm{~Hz},{ }^{2} J_{\mathrm{Si}-\mathrm{P}}=28.6 \mathrm{~Hz}, \mathrm{SiH}_{2} \mathrm{Ph}\right),-5.0(\mathrm{~d}$, $\left.{ }^{1} J_{\mathrm{Si}-\mathrm{H}}=186.0 \mathrm{~Hz},\left\{(\operatorname{SiHPh})_{2}\left(\mu-\mathrm{N}^{t} \mathrm{Bu}\right)\right\}\right), 1.4\left(\mathrm{ddd},{ }^{1} J_{\mathrm{Si}-\mathrm{H}}=166.9\right.$ $\left.\mathrm{Hz},{ }^{2} J_{\mathrm{Si}-\mathrm{P}}=25.0 \mathrm{~Hz},{ }^{2} J_{\mathrm{Si}-\mathrm{P}}=20.3 \mathrm{~Hz},\left\{(\mathrm{SiHPh})_{2}\left(\mu-\mathrm{N}^{t} \mathrm{Bu}\right)\right\}\right) .{ }^{29} \mathrm{Si}$ RF INEPT NMR (119.2 MHz, toluene- $d_{8},-18{ }^{\circ} \mathrm{C}, J=180 \mathrm{~Hz}$, $\delta, \quad \mathrm{ppm}): 1.4\left(\mathrm{dd},{ }^{2} J_{\mathrm{Si}-\mathrm{P}}=16.7 \mathrm{~Hz},{ }^{2} J_{\mathrm{Si}-\mathrm{P}}=28.6 \mathrm{~Hz}\right.$, $\left\{(\mathrm{SiHPh})_{2}\left(\mu-\mathrm{N}^{t} \mathrm{Bu}\right)\right\}, \quad$ up” $), \quad-5.1 \quad\left(\mathrm{~d},{ }^{2} J_{\mathrm{Si}-\mathrm{P}}=10.7 \mathrm{~Hz}\right.$, $\left\{(\mathrm{Si} \mathrm{HPh})_{2}\left(\mu-\mathrm{N}^{t} \mathrm{Bu}\right)\right\}$, "up”), $-14.7\left(\mathrm{t},{ }^{2} J_{\mathrm{Si}-\mathrm{P}}=23.8 \mathrm{~Hz}, \mathrm{Si}_{2} \mathrm{Ph}\right.$, 
“down”). ${ }^{1} \mathrm{H}-{ }^{31} \mathrm{P}$ HSQC JC NMR $\left(243.0 \mathrm{~Hz}\right.$, toluene-d $\mathrm{d}_{8} ;-20{ }^{\circ} \mathrm{C}$; $J=15 \mathrm{~Hz} ;{ }^{1} \mathrm{H}$ proj.; $\left.\delta, \mathrm{ppm}\right): 1.6\left(\mathrm{~d},{ }^{2} J_{\mathrm{H}-\mathrm{P}}=30.0 \mathrm{~Hz},\left\{(\mathrm{Si} H \mathrm{Ph})_{2^{-}}\right.\right.$ $\left.\left.\left(u-\mathrm{N}^{t} \mathrm{Bu}\right)\right\}\right) \cdot{ }^{13} \mathrm{C}\left\{{ }^{1} \mathrm{H}\right]-\mathrm{NMR}\left(151 \mathrm{MHz} ;\right.$ toluene-d $\mathrm{d}_{8}-28{ }^{\circ} \mathrm{C} ; \delta$, ppm): 14.9 (d, $\left.{ }^{1} J_{\mathrm{C}-\mathrm{P}}=18.1 \mathrm{~Hz}, \mathrm{PM} e_{3}\right), 19.1$ (d, ${ }^{1} J_{\mathrm{C}-\mathrm{P}}=24.1 \mathrm{~Hz}$, $\mathrm{PMe}_{3}$ ), $30.3\left(\mathrm{~s}, \mathrm{CH}_{3},{ }^{t} \mathrm{Bu}\right), 31.7\left(\mathrm{~s}, \mathrm{CH}_{3},{ }^{t} \mathrm{BuN}\right), 34.8\left(\mathrm{~s}, \mathrm{CH}_{3}\right.$, $\left.{ }^{t} B u \mathrm{~N}=\mathrm{Mo}\right), 54.7\left(\mathrm{~s}, C\left(\mathrm{CH}_{3}\right)_{3},{ }^{t} B u \mathrm{~N}\right), 127.3(\mathrm{~s}, m-\mathrm{C}, \mathrm{Si} P h), 127.5$ (s, $m$-C, SiPh), 128.1 (s, $m$-C, SiPh), 128.2 (s, p-C, SiPh), 128.4 (s, p-C, $\mathrm{Si} P h$ ), 133.9 (s, o-C, $\mathrm{Si} P h$ ), 137.1 (s, o-C, $\mathrm{Si} P h$ ), 137.8 (s, o-C, $\mathrm{Si} P h$ ), 143.2 (s, i-C, SiPh), 147.8 (s, i-C, SiPh), 148.8 (s, i-C, $\mathrm{Si} P h$ ). IR (nujol, $\mathrm{cm}^{-1}$ ): 1825 (m, Mo-H), 1890 (s, Si-H), 2037 (s, Si-H), 2142 (s, Si-H). Elem. Anal. (\%): calc. for $\mathrm{C}_{32} \mathrm{H}_{56} \mathrm{MoN}_{2} \mathrm{P}_{2} \mathrm{Si}_{3}$ (710.945) C 54.06, $\mathrm{H}$ 7.94, N 3.94; found C 53.99 H 7.87, N 4.22.

\section{General procedure for the addition of $\mathrm{PhSiH}_{3}$ on the NMR scale}

To a solution of $\left({ }^{t} \mathrm{BuN}\right) \mathrm{Mo}\left(\mathrm{PMe}_{3}\right)(\mathrm{L})\left(\mathrm{L}=\mathrm{PMe}_{3}(\mathbf{1}), \eta^{2}-\mathrm{C}_{2} \mathrm{H}_{4}(2)\right)$ in toluene- $\mathrm{d}_{8}, \mathrm{PMe}_{3}$ was added in one portion at room temperature. The sample was cooled to $-196{ }^{\circ} \mathrm{C}$ using liquid nitrogen on a Schlenk line and $\mathrm{PhSiH}_{3}$ was directly added. The sample was quickly removed from the liquid nitrogen and inverted once, and then immediately placed back. The sample was then placed in a pre-cooled NMR machine at an appropriate temperature and monitored at various temperatures. In some cases, the sample was allowed to react for 2-4 hours at $-40{ }^{\circ} \mathrm{C}$, and then monitored by $\mathrm{NMR}$ at an appropriate temperature.

$\left({ }^{t} \mathrm{BuN}\right) \mathrm{Mo}\left(\boldsymbol{\eta}^{3}-\mathrm{N}^{t} \mathrm{Bu}-\mathrm{SiHPh}-\mathrm{H}\right)\left(\mathrm{PMe}_{3}\right)_{2}(\mathrm{Et}) \quad$ (4). ${ }^{1} \mathrm{H}-\mathrm{NMR}$ (600 MHz, toluene- $\left.\mathrm{d}_{8},-53{ }^{\circ} \mathrm{C}, \delta, \mathrm{ppm}\right):-0.82$ (s, $1 \mathrm{H}, \mathrm{Si}-H_{a g}$, ${ }^{1} J_{\mathrm{Si}-\mathrm{H}}=125.1 \mathrm{~Hz}$, found by ${ }^{1} \mathrm{H}-{ }^{29} \mathrm{Si}$ HSQC $\left.1 \mathrm{D} \mathrm{JC}\right), 1.03(\mathrm{~s}, 9 \mathrm{H}$, $\left.3 \mathrm{CH}_{3},{ }^{t} \mathrm{Bu} \mathrm{N}=\mathrm{Mo}\right), 1.10\left(\mathrm{~s}, 9 \mathrm{H}, 3 \mathrm{CH}_{3}, \mathrm{Mo}-\mathrm{N}^{t} \mathrm{Bu}-\mathrm{SiH}_{2} \mathrm{Ph}\right), 1.32$ $\left(\mathrm{d}, 9 \mathrm{H}, \mathrm{PMe}_{3},{ }^{2} J_{\mathrm{H}-\mathrm{P}}=5.22 \mathrm{~Hz}\right), 1.43\left(\mathrm{~d}, 9 \mathrm{H}, \mathrm{PMe} e_{3},{ }^{2} J_{\mathrm{H}-\mathrm{P}}=5.28\right.$ $\mathrm{Hz}), 1.96\left(\mathrm{t}, 3 \mathrm{H}, \mathrm{CH}_{3}, \mathrm{Mo}-\mathrm{CH}_{2}-\mathrm{CH}_{3},{ }^{3} \mathrm{~J}_{\mathrm{H}-\mathrm{H}}=7.53 \mathrm{~Hz}\right), 2.50(\mathrm{~m}$, $\left.1 \mathrm{H}, \mathrm{Mo}-\mathrm{CH}_{2}-\mathrm{CH}_{3}\right), 2.61\left(\mathrm{~m}, 1 \mathrm{H}, \mathrm{Mo}-\mathrm{CH}_{2}-\mathrm{CH}_{3}\right), 5.66(\mathrm{~s}, 1 \mathrm{H}$, $\mathrm{Si}-H_{\text {class }},{ }^{1} J_{\mathrm{Si}-\mathrm{H}}=212.0 \mathrm{~Hz}$, found by ${ }^{1} \mathrm{H}^{2}{ }^{29} \mathrm{Si} \mathrm{HSQC}$ 1D JC), 7.27 (m, 2H, $m-\mathrm{Ph}$ ), 7.96 (d, 2H,o-Ph, $\left.{ }^{3} J_{\mathrm{H}-\mathrm{H}}=6.9 \mathrm{~Hz}\right) \cdot{ }^{31} \mathrm{P}\left\{{ }^{1} \mathrm{H}\right\}-\mathrm{NMR}$ (243.0 MHz, toluene- $\left.\mathrm{d}_{8},-53{ }^{\circ} \mathrm{C}, \delta, \mathrm{ppm}\right):-7.78$ (d, 1P, $\mathrm{PMe}_{3}$, $\left.{ }^{2} J_{\mathrm{P}-\mathrm{P}}=291.7 \mathrm{~Hz}\right),-10.12\left(\mathrm{~d}, 1 \mathrm{P}, \mathrm{PMe}_{3},{ }^{2} J_{\mathrm{P}-\mathrm{P}}=291.8 \mathrm{~Hz}\right)$. ${ }^{1} \mathrm{H}-{ }^{29} \mathrm{Si}$ HSQC NMR $\left(119.0 \mathrm{MHz}\right.$, toluene- $\mathrm{d}_{8} ;-53{ }^{\circ} \mathrm{C} ; J=$ $150 \mathrm{~Hz} ;{ }^{29} \mathrm{Si}$ projection, $\delta$, ppm): $-75.4\left(\mathrm{Mo}-\mathrm{N}^{t} \mathrm{Bu}-\mathrm{Si}_{2} \mathrm{Ph}\right)$.

$\left({ }^{t} \mathrm{BuN}\right) \mathrm{Mo}\left(\boldsymbol{\eta}^{3}-\mathbf{N}^{t} \mathrm{Bu}-\mathrm{SiHPh}-\mathrm{H}\right)\left(\mathrm{PMe}_{3}\right)_{2}\left(\mathrm{SiH}_{2} \mathrm{Ph}\right) \quad$ (5). ${ }^{1} \mathrm{H}-\mathrm{NMR}$ (600 MHz, toluene- $\left.\mathrm{d}_{8},-78{ }^{\circ} \mathrm{C}, \delta, \mathrm{ppm}\right): 0.17$ (s, $1 \mathrm{H}, \mathrm{Si}-H_{a g}$, ${ }^{1} J_{\mathrm{Si}-\mathrm{H}}=110.3 \mathrm{~Hz}$, found by ${ }^{1} \mathrm{H}-{ }^{29} \mathrm{Si}$ HSQC $\left.1 \mathrm{D} \mathrm{JC}\right), 1.00(\mathrm{~s}, 9 \mathrm{H}$, $3 \mathrm{CH}_{3},{ }^{t} \mathrm{Bu}=\mathrm{No}=1.35$ (bs, $18 \mathrm{H}, 2 \mathrm{PMe}_{3}$ ), 1.37 (s, 9H, $3 \mathrm{CH}_{3}$, $\left.\mathrm{Mo}-\mathrm{N}^{t} \mathrm{Bu}-\mathrm{SiH}_{2} \mathrm{Ph}\right), 5.43\left(\mathrm{~s}, 1 \mathrm{H}, \mathrm{Si}-H_{\text {class }},{ }^{1} J_{\mathrm{Si}-\mathrm{H}}=226.1 \mathrm{~Hz}\right.$, found by ${ }^{1} \mathrm{H}^{29}{ }^{29} \mathrm{Si}$ HSQC $1 \mathrm{D}$ JC), 5.76 (s, 1H, Mo-Si $\mathrm{H}_{2} \mathrm{Ph}$ ), 5.81 (s, $\left.1 \mathrm{H}, \mathrm{Mo}-\mathrm{Si} H_{2} \mathrm{Ph}\right), 7.23\left(\mathrm{t}, 2 \mathrm{H}, m-\mathrm{Ph}, \mathrm{Mo}-\mathrm{N}^{t} \mathrm{BuSiH} P h,{ }^{3} J_{\mathrm{H}-\mathrm{H}}=\right.$ $7.26 \mathrm{~Hz}$ ), 7.37 (t, 2H, $m-\mathrm{Ph}, \mathrm{Mo}-\mathrm{SiH}_{2} P h,{ }^{3} J_{\mathrm{H}-\mathrm{H}}=7.23 \mathrm{~Hz}$ ), 7.84 (d, 2H, $\left.o-\mathrm{Ph}, \mathrm{Mo}-\mathrm{N}^{t} \mathrm{BuSiH} P h,{ }^{3} J_{\mathrm{H}-\mathrm{H}}=6.84 \mathrm{~Hz}\right), 8.22(\mathrm{~d}, 2 \mathrm{H}$, $o$-Ph, Mo-SiH $\left.{ }_{2} P h,{ }^{3} J_{\mathrm{H}-\mathrm{H}}=6.98 \mathrm{~Hz}\right) .{ }^{31} \mathrm{P}\left\{{ }^{1} \mathrm{H}\right\}-\mathrm{NMR}(243.0 \mathrm{MHz}$, toluene- $\left.\mathrm{d}_{8},-72{ }^{\circ} \mathrm{C}, \delta, \mathrm{ppm}\right):-10.9\left(\mathrm{~d}, 1 \mathrm{P}, \mathrm{PMe}_{3},{ }^{2} J_{\mathrm{P}-\mathrm{P}}=\right.$ $268.2 \mathrm{~Hz}$ ), -13.0 (d, 1P, $\mathrm{PMe}_{3},{ }^{2} J_{\mathrm{P}-\mathrm{P}}=266.8 \mathrm{~Hz}$ ). ${ }^{1} \mathrm{H}-{ }^{29} \mathrm{Si} \mathrm{HSQC}$ NMR (119.0 MHz, toluene- $\mathrm{d}_{8} ;-53{ }^{\circ} \mathrm{C} ; J=150 \mathrm{~Hz} ;{ }^{29} \mathrm{Si}$ proj., $\delta, \mathrm{ppm}):-8.4\left(\mathrm{Mo}-\mathrm{SiH}_{2} \mathrm{Ph}\right),-81.1\left(\mathrm{Mo}-\mathrm{N}^{t} \mathrm{Bu}-S i \mathrm{H}_{2} \mathrm{Ph}\right)$.

$\left({ }^{t} \mathrm{BuN}\right) \mathrm{Mo}(\mathrm{H})\left(\eta^{3}-\mathrm{PhHSi}-\mathrm{N}\left({ }^{t} \mathrm{Bu}\right)-\mathrm{SiHPh}-\mathrm{H}\right)\left(\mathrm{PMe}_{3}\right)_{2} \quad(6) .{ }^{1} \mathrm{H}-\mathrm{NMR}$ $\left(600 \mathrm{MHz}\right.$, toluene- $\left.\mathrm{d}_{8},-41{ }^{\circ} \mathrm{C}, \delta, \mathrm{ppm}\right):-4.63\left(\mathrm{dd}, 1 \mathrm{H},{ }^{2} J_{\mathrm{H}-\mathrm{P}}=\right.$
$54.9 \mathrm{~Hz},{ }^{2} J_{\mathrm{H}-\mathrm{P}}=19.5 \mathrm{~Hz}, \mathrm{MoH}$, minor isomer), -4.43 (ddd, $1 \mathrm{H}$, ${ }^{2} J_{\mathrm{H}-\mathrm{P}}=46.1 \mathrm{~Hz},{ }^{2} J_{\mathrm{H}-\mathrm{P}}=16.7 \mathrm{~Hz},{ }^{2} J_{\mathrm{H}-\mathrm{H}}=4.4 \mathrm{~Hz}, \mathrm{MoH}$, major isomer), 0.37 (dt, $1 \mathrm{H},{ }^{2} J_{\mathrm{H}-\mathrm{P}}=45.5 \mathrm{~Hz},{ }^{2} J_{\mathrm{H}-\mathrm{H}}=4.4 \mathrm{~Hz}, \mathrm{Si} H_{a g}$, major isomer), $0.81\left(\mathrm{~d}, 9 \mathrm{H},{ }^{2} J_{\mathrm{H}-\mathrm{P}}=7.3 \mathrm{~Hz}, \mathrm{PMe}{ }_{3}\right.$, major isomer), $0.88\left(\mathrm{~d}, 9 \mathrm{H},{ }^{2} J_{\mathrm{H}-\mathrm{P}}=7.3 \mathrm{~Hz}, \mathrm{PMe}_{3}\right.$, major isomer), $1.36(\mathrm{~s}, 9 \mathrm{H}$, ${ }^{t} \mathrm{Bu} \mathrm{N}=\mathrm{Mo}$, major isomer), 1.44 (s, 9H, $\mu-\mathrm{N}^{t} \mathrm{Bu}$, major isomer), $6.84\left(\mathrm{bd}, 1 \mathrm{H},{ }^{2} J_{\mathrm{H}-\mathrm{H}}=5.3 \mathrm{~Hz}, \mathrm{Si} H_{\text {class }}\right.$, major isomer), 6.92 (bs, 1H, Mo-SiHPh, major isomer), 7.22 (bs, 1H, Mo-SiHPh, minor isomer), $7.23\left(\mathrm{t}, 1 \mathrm{H},{ }^{3} J_{\mathrm{H}-\mathrm{H}}=7.4 \mathrm{~Hz}, p-\mathrm{H}, \mathrm{Mo}-\mathrm{SiH} P h\right.$, major isomer), $7.27\left(\mathrm{t}, 1 \mathrm{H}, p-\mathrm{H},{ }^{3} J_{\mathrm{H}-\mathrm{H}}=7.4 \mathrm{~Hz}, \mathrm{SiH}_{2} P h\right.$, major isomer), $7.36\left(\mathrm{t}, 1 \mathrm{H},{ }^{3} J_{\mathrm{H}-\mathrm{H}}=7.1 \mathrm{~Hz}, m-\mathrm{H}, \mathrm{Mo}-\mathrm{SiH} P h\right.$, major isomer), $7.43\left(\mathrm{t}, \quad 2 \mathrm{H}, \quad m-\mathrm{H}, \quad \mathrm{SiH}_{2} P h,{ }^{3} J_{\mathrm{H}-\mathrm{H}}=7.3 \mathrm{~Hz}\right.$, major isomer), 7.47 (t, 1H, $m-\mathrm{H}, \mathrm{Mo}-\mathrm{SiH} P h,{ }^{3} J_{\mathrm{H}-\mathrm{H}}=6.9 \mathrm{~Hz}$, major isomer), 8.25 (bd, $1 \mathrm{H}, o-\mathrm{H}, \mathrm{Mo}-\mathrm{SiH} P h,{ }^{3} J_{\mathrm{H}-\mathrm{H}}=6.2 \mathrm{~Hz}$, major isomer), 8.39 (bs, $2 \mathrm{H}, o-\mathrm{H}, \mathrm{SiH}_{2} P h,{ }^{3} \mathrm{~J}_{\mathrm{H}-\mathrm{H}}=7.3 \mathrm{~Hz}$, major isomer), 8.56 (bd, $1 \mathrm{H}, o-\mathrm{H}, \mathrm{Mo}-\mathrm{SiH} P h,{ }^{3} J_{\mathrm{H}-\mathrm{H}}=6.3 \mathrm{~Hz}$, major isomer). ${ }^{31} \mathrm{P}\left\{{ }^{1} \mathrm{H}\right\}$-NMR (243.0 MHz, toluene- $\left.\mathrm{d}_{8},-25{ }^{\circ} \mathrm{C}, \delta, \mathrm{ppm}\right): 2.4(\mathrm{~d}$, ${ }^{2} J_{\mathrm{P}-\mathrm{P}}=43.7 \mathrm{~Hz}, \mathrm{PMe}_{3}$, minor isomer), -0.8 (d, ${ }^{2} J_{\mathrm{P}-\mathrm{P}}=43.7 \mathrm{~Hz}$, $\mathrm{PMe}_{3}$, major isomer), -5.1 (d, ${ }^{2} J_{\mathrm{P}-\mathrm{P}}=43.7 \mathrm{~Hz}, \mathrm{PMe}_{3}$, minor isomer), -7.0 (d, ${ }^{2} \mathrm{P}_{\mathrm{P}-\mathrm{P}}=43.7 \mathrm{~Hz}, \mathrm{PMe}_{3}$, major isomer). ${ }^{29} \mathrm{Si}$ INEPT+ NMR $\left(119 \mathrm{MHz}\right.$, toluene-d $\mathrm{d}_{8},-40{ }^{\circ} \mathrm{C}, J=200 \mathrm{~Hz}, \delta$, ppm): $-19.5\left(\mathrm{dd},{ }^{1} J_{\mathrm{H}-\mathrm{Si}}=37.3 \mathrm{~Hz},{ }^{1} J_{\mathrm{H}-\mathrm{Si}}=199.8 \mathrm{~Hz}, \mathrm{SiH}_{2} \mathrm{Ph}\right.$, minor isomer), $-16.2\left(\mathrm{dd},{ }^{1} J_{\mathrm{H}-\mathrm{Si}}=34.9 \mathrm{~Hz},{ }^{1} J_{\mathrm{H}-\mathrm{Si}}=195.6 \mathrm{~Hz}\right.$, $\mathrm{SiH}_{2} \mathrm{Ph}$, major isomer), 5.2 (d, ${ }^{1} J_{\mathrm{H}-\mathrm{Si}}=172.3 \mathrm{~Hz}, \mathrm{SiHPh}$, major isomer), $7.5\left(\mathrm{~d},{ }^{1} J_{\mathrm{H}-\mathrm{Si}}=182.7 \mathrm{~Hz}, \mathrm{SiHPh}\right.$, minor isomer). ${ }^{13} \mathrm{C}\left\{{ }^{1} \mathrm{H}\right\}$-NMR (151 MHz; toluene- $\mathrm{d}_{8} ;-40{ }^{\circ} \mathrm{C} ; \delta$, ppm): 19.89 (d, $\left.\mathrm{PMe}_{3},{ }^{1} J_{\mathrm{C}-\mathrm{P}}=23.8 \mathrm{~Hz}\right), 22.65\left(\mathrm{~d}, \mathrm{PMe}_{3},{ }^{1} J_{\mathrm{C}-\mathrm{P}}=24.8 \mathrm{~Hz}\right), 31.35$ (s, $\left.\mathrm{CH}_{3},{ }^{t} \mathrm{BuN}\right), 31.97\left(\mathrm{~s}, \mathrm{CH}_{3},{ }^{t} \mathrm{BuN}\right), 54.54\left(\mathrm{~s}, C\left(\mathrm{CH}_{3}\right)_{3},{ }^{t} \mathrm{BuN}\right)$, $65.70\left(\mathrm{~s}, C\left(\mathrm{CH}_{3}\right)_{3},{ }^{t} \mathrm{BuN}\right), 127-130(p-\mathrm{Ph}, m$-Ph, overlapped with solvent signals, found by ${ }^{1} \mathrm{H}^{-}{ }^{13} \mathrm{C}$ HSQC), $134.0(o-\mathrm{Ph}$, MoSiHPh), 137.1 (o-Ph, SiPh), 149.2 (i-Ph, SiPh), 151.0 (i-Ph, $\mathrm{Si} P h)$.

$\left({ }^{t} \mathrm{BuN}\right) \mathbf{M o}\left\{(\mathbf{S i H P h})_{2}\left(\boldsymbol{\mu}-\mathbf{N}^{t} \mathbf{B u}\right)\right\}\left(\mathbf{P M e}_{3}\right)_{2} \mathbf{H}_{2}(7) .{ }^{1} \mathrm{H}-\mathrm{NMR}(600 \mathrm{MHz}$, toluene- $\left.\mathrm{d}_{8}, 0{ }^{\circ} \mathrm{C}, \delta, \mathrm{ppm}\right): 0.80\left(\mathrm{~s}, 9 \mathrm{H}, 3 \mathrm{CH}_{3}, \mathrm{Mo}=\mathrm{N}^{t} \mathrm{Bu}\right), 1.05$ $\left(\mathrm{d}, 9 \mathrm{H}, \mathrm{PMe}_{3},{ }^{2} \mathrm{~J}_{\mathrm{H}-\mathrm{P}}=7.7 \mathrm{~Hz}\right), 1.10\left(\mathrm{~d}, 9 \mathrm{H}, \mathrm{PMe}{ }_{3},{ }^{2} J_{\mathrm{H}-\mathrm{P}}=6.7 \mathrm{~Hz}\right)$, 1.25 (MoH, found by ${ }^{1} \mathrm{H}-{ }^{1} \mathrm{H}$ COSY and ${ }^{1} \mathrm{H}-{ }^{29} \mathrm{Si} H S Q C(J=$ $7 \mathrm{~Hz}$ ), partially obscured by complex 3) $1.39\left(\mathrm{~s}, 9 \mathrm{H}, 3 \mathrm{CH}_{3}\right.$, $\mathrm{Si}-\mathrm{N}^{t} \mathrm{Bu}-\mathrm{Si}$ ), 1.48 (Mo-H, found by ${ }^{1} \mathrm{H}-{ }^{1} \mathrm{H} \mathrm{COSY}$ and ${ }^{1} \mathrm{H}-{ }^{29} \mathrm{Si}$ HSQC $(J=7 \mathrm{~Hz})$, partially obscured by complex 3), 5.92 (ddd, $1 \mathrm{H}, \mathrm{SiH},{ }^{3} J_{\mathrm{H}-\mathrm{H}}=3.8 \mathrm{~Hz},{ }^{3} J_{\mathrm{H}-\mathrm{P}}=5.93 \mathrm{~Hz},{ }^{2} J_{\mathrm{H}-\mathrm{P}}=11.57 \mathrm{~Hz},{ }^{1} J_{\mathrm{Si}-\mathrm{H}}$ $=169.2 \mathrm{~Hz}$ \{found by ${ }^{1} \mathrm{H}-{ }^{29} \mathrm{Si} H S Q C ~ 1 \mathrm{D} \mathrm{JC}$ ), $6.51(\mathrm{dt}, 1 \mathrm{H}, \mathrm{Si} H$, ${ }^{3} J_{\mathrm{H}-\mathrm{H}}=6.1 \mathrm{~Hz},{ }^{2} J_{\mathrm{H}-\mathrm{P}}=6.1 \mathrm{~Hz},{ }^{2} J_{\mathrm{H}-\mathrm{P}}=12.2 \mathrm{~Hz},{ }^{1} J_{\mathrm{Si}-\mathrm{H}}=187.1 \mathrm{~Hz}$ \{found by ${ }^{1} \mathrm{H}-{ }^{29} \mathrm{Si}$ HSQC $\left.\left.1 \mathrm{D} \mathrm{JC}\right\}\right), 8.33\left(\mathrm{~d}, 2 \mathrm{H}, o-\mathrm{Ph},{ }^{3} J_{\mathrm{H}-\mathrm{H}}=\right.$ $6.9 \mathrm{~Hz}) .{ }^{1} \mathrm{H}\left\{{ }^{31} \mathrm{P}\right\}$-NMR $\left(600 \mathrm{MHz}\right.$, toluene- $\mathrm{d}_{8}, 0{ }^{\circ} \mathrm{C}, \delta, \mathrm{ppm}$, selected resonances): $6.51\left(\mathrm{~d}, 1 \mathrm{H}, \mathrm{SiH},{ }^{3} \mathrm{~J}_{\mathrm{H}-\mathrm{H}}=6.12 \mathrm{~Hz}\right), 5.92$ (bd, $1 \mathrm{H}, \mathrm{SiH},{ }^{3} J_{\mathrm{H}-\mathrm{H}}=3.7 \mathrm{~Hz}$ ), 1.10 (s, PMe $e_{3}$ ), 1.05 (s, $\mathrm{PMe}_{3}$ ). ${ }^{31} \mathrm{P}\left\{{ }^{1} \mathrm{H}\right\}$-NMR (243.0 MHz, toluene- $\left.\mathrm{d}_{8}, 0{ }^{\circ} \mathrm{C}, \delta, \mathrm{ppm}\right):-9.65(\mathrm{~d}$, $\left.1 \mathrm{P}, \mathrm{PMe}_{3},{ }^{2} J_{\mathrm{P}-\mathrm{P}}=31.3 \mathrm{~Hz}\right),-34.60\left(\mathrm{~d}, 1 \mathrm{P}, \mathrm{PMe}_{3},{ }^{2} J_{\mathrm{P}-\mathrm{P}}=31.1\right.$ Hz). ${ }^{31} \mathrm{P}\left\{{ }^{1} \mathrm{H}\right\}-N M R$ (selectively decoupled from Me groups at $1.10 \mathrm{ppm}$ in ${ }^{1} \mathrm{H}-\mathrm{NMR}, 243.0 \mathrm{MHz}$, toluene- $\left.\mathrm{d}_{8}, 0{ }^{\circ} \mathrm{C}, \delta, \mathrm{ppm}\right)$ : -9.63 (bt, 1P, $\left.\mathrm{PMe}_{3},{ }^{2} J_{\mathrm{P}-\mathrm{P}}=33.4 \mathrm{~Hz}\right),-34.49\left(\mathrm{~m}, 1 \mathrm{P}, \mathrm{PMe}_{3}\right.$, $\left.{ }^{3} J_{\mathrm{P}-\mathrm{H}}=13.0 \mathrm{~Hz},{ }^{2} J_{\mathrm{P}-\mathrm{P}}=27.6 \mathrm{~Hz},{ }^{2} J_{\mathrm{P}-\mathrm{H}}=51.7 \mathrm{~Hz}\right) .{ }^{31} \mathrm{P}\left\{{ }^{1} \mathrm{H}\right\}-\mathrm{NMR}$ (selectively decoupled from $\mathrm{Me}$ groups at $1.05 \mathrm{ppm}$ in ${ }^{1} \mathrm{H}-\mathrm{NMR}, 243.0 \mathrm{MHz}$, toluene- $\left.\mathrm{d}_{8}, 0{ }^{\circ} \mathrm{C}, \delta, \mathrm{ppm}\right):-9.63(\mathrm{dd}, 1 \mathrm{P}$, $\mathrm{PMe}_{3},{ }^{2} J_{\mathrm{P}-\mathrm{P}}=33.4 \mathrm{~Hz},{ }^{2} J_{\mathrm{P}-\mathrm{H}}=33.4 \mathrm{~Hz}$ ), -34.70 (m, 1P, $\mathrm{PMe}_{3}$ ). ${ }^{31} \mathrm{P}\left\{{ }^{1} \mathrm{H}\right\}$-NMR (selectively decoupled from hydride at $1.25 \mathrm{ppm}$ 
in ${ }^{1} \mathrm{H}-\mathrm{NMR}, 243.0 \mathrm{MHz}$, toluene- $\left.\mathrm{d}_{8}, 0{ }^{\circ} \mathrm{C}, \delta, \mathrm{ppm}\right):-9.63(\mathrm{~d}, 1 \mathrm{P}$, $\left.\mathrm{PMe}_{3},{ }^{2} J_{\mathrm{P}-\mathrm{P}}=33.4 \mathrm{~Hz}\right),-34.60\left(\mathrm{~m}, 1 \mathrm{P}, \mathrm{PMe}_{3}\right) .{ }^{29} \mathrm{Si}$ INEPT+ NMR (119 MHz, toluene- $\left.\mathrm{d}_{8}, 0{ }^{\circ} \mathrm{C}, J=150 \mathrm{~Hz}, \delta, \mathrm{ppm}\right): 4.05\left(\mathrm{~d},{ }^{1} J_{\mathrm{Si}-\mathrm{H}}=\right.$ $170.0 \mathrm{~Hz}),-2.17\left(\mathrm{~d},{ }^{1} J_{\mathrm{Si}-\mathrm{H}}=185.3 \mathrm{~Hz}\right)$.

$\left({ }^{t} \mathrm{BuN}\right)\left\{\boldsymbol{\mu}-{ }^{t} \mathrm{BuN}(\mathrm{SiHPh})_{2}\right\} \mathbf{M o}\left(\mathrm{PMe}_{3}\right)_{3} \quad$ (8). ${ }^{1} \mathrm{H}-\mathrm{NMR}(600 \mathrm{MHz}$, toluene- $\left.\mathrm{d}_{8}, 0{ }^{\circ} \mathrm{C}, \delta, \mathrm{ppm}\right): 0.90\left(\mathrm{~d}, 9 \mathrm{H}, \mathrm{PMe}{ }_{3},{ }^{2} J_{\mathrm{H}-\mathrm{P}}=6.78 \mathrm{~Hz}\right)$, $1.06\left(\mathrm{~s}, 9 \mathrm{H}, 3 \mathrm{CH}_{3},{ }^{t} \mathrm{Bu} \mathrm{N}=\mathrm{Mo}\right), 1.26\left(\mathrm{~d}, 9 \mathrm{H}, \mathrm{PMe}_{3},{ }^{2} \mathrm{~J}_{\mathrm{H}-\mathrm{P}}=\right.$ $6.12 \mathrm{~Hz}), 1.45\left(\mathrm{~s}, 9 \mathrm{H}, 3 \mathrm{CH}_{3}, \mu-\mathrm{N}^{t} \mathrm{Bu}\right), 1.74\left(\mathrm{~d}, 9 \mathrm{H}, \mathrm{PMe}_{3},{ }^{2} J_{\mathrm{H}-\mathrm{P}}=\right.$ $6.90 \mathrm{~Hz}$ ), 5.36 (ddd, $1 \mathrm{H}, \mathrm{MoSi} H \mathrm{Ph},{ }^{1} J_{\mathrm{Si}-\mathrm{H}}=226.1 \mathrm{~Hz}$, found by ${ }^{1} \mathrm{H}-{ }^{29} \mathrm{Si} \mathrm{HSQC} 1 \mathrm{D} \mathrm{JC},{ }^{2} J_{\mathrm{H}-\mathrm{P}}=3.00 \mathrm{~Hz},{ }^{2} J_{\mathrm{H}-\mathrm{P}}=4.98 \mathrm{~Hz},{ }^{2} J_{\mathrm{H}-\mathrm{P}}=$ $7.80 \mathrm{~Hz}$ ), 7.05 (bd, $1 \mathrm{H}, \mathrm{MoSi} H \mathrm{Ph},{ }^{1} J_{\mathrm{Si}-\mathrm{H}}=226.1 \mathrm{~Hz}$, found by ${ }^{1} \mathrm{H}^{29}{ }^{29} \mathrm{Si}$ HSQC 1D JC, partially obscured by solvent signals), $7.29\left(\mathrm{t}, 2 \mathrm{H}, m-\mathrm{Ph},{ }^{3} J_{\mathrm{H}-\mathrm{H}}=7.56 \mathrm{~Hz}\right), 7.47\left(\mathrm{t}, 2 \mathrm{H}, m-\mathrm{Ph},{ }^{3} J_{\mathrm{H}-\mathrm{H}}=\right.$ $7.47 \mathrm{~Hz}$ ), 7.96 (d, 2H, o-Ph, $\left.{ }^{3} J_{\mathrm{H}-\mathrm{H}}=7.08 \mathrm{~Hz}\right), 8.27$ (d, $2 \mathrm{H}, o-\mathrm{Ph}$, $\left.{ }^{3} J_{\mathrm{H}-\mathrm{H}}=6.96 \mathrm{~Hz}\right) \cdot{ }^{1} \mathrm{H}\left\{{ }^{31} \mathrm{P}\right\}-\mathrm{NMR}\left(600 \mathrm{MHz}\right.$, toluene-d $\mathrm{d}_{8}, 0{ }^{\circ} \mathrm{C}, \delta$, ppm; selected resonances): $0.90\left(\mathrm{~s}, 9 \mathrm{H}, \mathrm{PMe}_{3}\right), 1.26(\mathrm{~s}, 9 \mathrm{H}$, $\mathrm{PMe}_{3}$ ), 1.74 (s, 9H, PMe $e_{3}$ ), 5.36 (s, 1H, MoSiHPh), 7.05 (s, 1H, MoSi HPh). ${ }^{31} \mathrm{P}\left\{{ }^{1} \mathrm{H}\right\}-\mathrm{NMR}\left(243.0 \mathrm{MHz}\right.$, toluene-d $\mathrm{d}_{8}, 0{ }^{\circ} \mathrm{C}, \delta$, ppm): 5.66 (t, 1P, $\mathrm{PMe}_{3},{ }^{2} J_{\mathrm{P}-\mathrm{P}}=22.6 \mathrm{~Hz}$ ), -7.48 (dd, 1P, $\mathrm{PMe}_{3}$, $\left.{ }^{2} J_{\mathrm{P}-\mathrm{P} \text { cis }}=18.2 \mathrm{~Hz},{ }^{2} J_{\mathrm{P}-\mathrm{P} \text { trans }}=91.1 \mathrm{~Hz}\right),-13.54\left(\mathrm{dd}, 1 \mathrm{P}, \mathrm{PMe}_{3}\right.$, $\left.{ }^{2} J_{\mathrm{P}-\mathrm{P} \text { cis }}=27.4 \mathrm{~Hz},{ }^{2} J_{\mathrm{P}-\mathrm{P} \text { trans }}=91.2 \mathrm{~Hz}\right) .{ }^{29} \mathrm{Si}$ INEPT $+\mathrm{NMR}$ (119 MHz, toluene- $\mathrm{d}_{8}, 0{ }^{\circ} \mathrm{C}, J=150 \mathrm{~Hz}, \delta, \mathrm{ppm}$ ): 41.70 (bd, $\left.{ }^{1} J_{\mathrm{Si}-\mathrm{H}}=169.3 \mathrm{~Hz}\right),-10.42\left(\mathrm{dddd}, \mathrm{Mo}-\mathrm{SiHPh},{ }^{1} J_{\mathrm{Si}-\mathrm{H}}=152.0 \mathrm{~Hz}\right.$, $\left.{ }^{2} J_{\mathrm{Si}-\mathrm{P}}=19.3 \mathrm{~Hz},{ }^{2} J_{\mathrm{Si}-\mathrm{P}}=19.3 \mathrm{~Hz},{ }^{2} J_{\mathrm{Si}-\mathrm{P}}=38.3 \mathrm{~Hz}\right)$.

\section{DFT calculations}

The unconstrained geometry optimization was carried out for all the considered structures with the Gaussian03 program package $^{30}$ using DFT and applying Becke three parameter hybrid exchange functional in conjunction with the gradientcorrected nonlocal correlation functional of Perdew and Wang (B3PW91). ${ }^{31}$ The 6-31G(d,p) basis set was used for the H, C, N, $\mathrm{O}, \mathrm{Si}, \mathrm{P}$ and $\mathrm{Cl}$ atoms. The Hay-Wadt effective core potentials (ECP) and the corresponding VDZ basis sets were used for the Mo atoms. ${ }^{32}$ The same level of theory was used in the frequency calculations performed at all the located stationary points. The thermodynamic parameters were calculated in the rigid rotor-harmonic oscillator approximation. For all the located transition state structures, the minimum energy reaction paths were investigated using the Gonzales-Schlegel method. ${ }^{33}$ The solvent effect was assessed using the polarizable continuum model (PCM). ${ }^{26}$ The standard solvent parameters for benzene were used as implemented in the Gaussian program along with the same theory level and basis sets as those used in the gas phase calculations.

\section{Crystal structure determination}

Single crystals of complex 3, suitable for X-ray diffraction analysis, were grown from $\mathrm{Et}_{2} \mathrm{O}$ solution at $-80{ }^{\circ} \mathrm{C}$. The crystals were mounted in a film of perfluoropolyether oil on a glass fibre and transferred to a Siemens three-circle diffractometer with a CCD detector (SMART-1K system). The crystals represented non-systematic twins and thus were of a rather poor quality. Nevertheless, we have managed to carry out indexing reflections although the data file contained many odd reflections. The data were corrected for Lorentz and polarization

Table 2 Crystal and structure refinement data for 3

3

\begin{tabular}{|c|c|}
\hline Empirical formula & $\mathrm{C}_{32} \mathrm{H}_{55} \mathrm{MoN}_{2} \mathrm{P}_{2} \mathrm{Si}_{3}$ \\
\hline Formula weight & 710.94 \\
\hline Crystal size $\left(\mathrm{mm}^{3}\right)$ & $0.22 \times 0.10 \times 0.08$ \\
\hline Crystal system & Monoclinic \\
\hline Space group & $P 2_{1} / n$ \\
\hline Unit cell dimensions: & \\
\hline$a(\AA)$ & 10.893(3) \\
\hline$b(\AA)$ & $22.133(7)$ \\
\hline$c(\AA)$ & $15.524(5)$ \\
\hline$\beta\left({ }^{\circ}\right)$ & $100.687(14)$ \\
\hline Volume $\left(\AA^{3}\right)$ & $3678(2)$ \\
\hline$Z$ & 4 \\
\hline Density (calculated) $\left(\mathrm{g} \mathrm{cm}^{-3}\right)$ & 1.284 \\
\hline Absorption coefficient $\left(\mathrm{mm}^{-1}\right)$ & 0.565 \\
\hline$F(000)$ & 1504 \\
\hline Diffractometer & Bruker SMART-1K \\
\hline Temperature (K) & $123(2)$ \\
\hline Radiation $(\lambda, \AA)$ & $(0.71073) \mathrm{Mo} \mathrm{K}_{\alpha}$ \\
\hline Scan mode & $\omega$ \\
\hline Time per step (s) & 15 \\
\hline Theta range for data collection $\left({ }^{\circ}\right)$ & $1.62-27.50$ \\
\hline Index ranges & $\begin{array}{l}-14 \leq h \leq 14,-28 \leq k \leq 28 \\
-20 \leq l \leq 20\end{array}$ \\
\hline Reflections collected & 24037 \\
\hline Independent reflections & 8295 \\
\hline Absorption correction & Multi-scan \\
\hline Max. transmission & 0.9562 \\
\hline Min. transmission & 0.8858 \\
\hline Refinement method & Full-matrix least-square on $F^{2}$ \\
\hline Data/restraints/parameters & $8295 / 0 / 362$ \\
\hline Goodness-of-fit on $F^{2}$ & 0.742 \\
\hline Final $R$ indices $[I>2 \sigma(I)]$ & $0.0960(0.2055)$ \\
\hline$R$ Indices (all data) & $0.3144(0.2650)$ \\
\hline Largest diff. peak and hole $\left(\mathrm{e} \AA^{-3}\right.$ ) & 0.919 and -0.887 \\
\hline
\end{tabular}

effects. The structure was solved by direct methods ${ }^{34}$ and refined by full-matrix least squares procedures. ${ }^{35}$ All nonhydrogen atoms were refined anisotropically. The hydrogen atoms except the hydrides were placed in calculated positions and refined in the "riding" model. The Mo-bound hydride was positionally refined isotropically. The hydrogen atoms bound to silicon atoms were also located from Fourier difference synthesis but their positions were not refined. One of the methyl groups of the ${ }^{t} \mathrm{Bu}$ fragment at the $\mathrm{N} 2$ atom is disordered over two positions with the ratio of occupancies of $0.6: 0.4$. The crystallographic data and the characteristics of structure solution and refinement are given in Table 2. Although the geometric positions of light atoms were obtained with not too high accuracy, the total image of the molecular structure is certainly correct and the distances between heavy atoms are accurate enough to discuss them in the article.

\section{Acknowledgements}

This work was supported by the NSERC (a DG to GIN), the Russian Fund for Basic Research (grants to SKI and LGK), an OGS fellowship to AYK and the Dean of Graduate Studies fellowship to NAM. GIN further thanks the CFI/OIT for a generous equipment grant. 


\section{Notes and references}

1 (a) Hydrosilylation, Advances in Silicon Science, ed. B. Marciniec, Springer, 2009; (b) A. K. Roy, Adv. Organomet. Chem., 2008, 55, 1; (c) R. Noyori, Asymmetric Catalysis in Organic Synthesis, John Wiley \& Sons, New York, 1994; (d) Catalytic Asymmetric Synthesis, ed. I. Ojima, Wiley, New York, 3rd edn, 2010; (e) H. Brunner and W. Zettimeier, Handbook of Enantioselective Catalysis with Transition Metal Compounds, VCH, Weinheim, 1993; $(f)$ I. Ojima, in The Chemistry of Organic Silicon Compounds, ed. S. Patai and Z. Rappoport, Wiley, NY, 1989, ch. 25.

2 (a) B.-H. Kim and H.-G. Woo, Adv. Organomet. Chem., 2005, 53, 143; (b) B.-H. Kim, M.-S. Cho and H.-G. Woo, Synlett, 2004, 0761.

3 See, for example: (a) S. E. Denmark and C. S. Regens, Acc. Chem. Res., 2008, 41, 1486; (b) Y. Nakao, M. Takeda, T. Matsumoto and T. Hiyama, Angew. Chem., Int. Ed., 2010, $122,4549$.

4 J. Y. Corey, Chem. Rev., 2011, 111, 863.

5 Y.-H. Li, Y. Zhang and S. Shimada, J. Organomet. Chem., 2010, 695, 2057.

6 R. H. Heyn and T. D. Tilley, J. Am. Chem. Soc., 1992, 114, 1919.

7 S. Shimada, M. L. N. Rao, T. Hayashi and M. Tanaka, Angew. Chem., Int. Ed., 2001, 40, 213.

8 (a) W. Chen, S. Shimada and M. Tanaka, Science, 2002, 295, 308; (b) G. Aullon, A. Lledos and S. Alvarez, Angew. Chem., Int. Ed., 2002, 41, 1956; (c) E. C. Scherer, C. R. Kinsinger, B. L. Kormos, J. D. Thompson and C. J. Cramer, Angew. Chem., Int. Ed., 2002, 41, 1953; (d) G. I. Nikonov, Angew. Chem., Int. Ed., 2003, 42, 1335.

9 M. D. Spencer, Q. D. Shelby and G. S. Girolami, J. Am. Chem. Soc., 2007, 129, 1860.

10 (a) S. K. Ignatov, A. Y. Khalimon, N. H. Rees, A. G. Razuvaev, P. Mountford and G. I. Nikonov, Inorg. Chem., 2009, 48, 9605; (b) S. K. Ignatov, N. H. Rees, S. R. Dubberley, A. G. Razuvaev, P. Mountford and G. I. Nikonov, Chem. Commun., 2004, 952.

11 A. Y. Khalimon, R. Simionescu, L. G. Kuzmina, J. A. K. Howard and G. I. Nikonov, Angew. Chem., Int. Ed., 2008, 47, 7701.

12 A. Y. Khalimon, R. Simionescu and G. I. Nikonov, J. Am. Chem. Soc., 2011, 133, 7033.

13 (a) U. Burckhardt, G. L. Casty, J. Gavenonis and T. D. Tilley, Organometallics, 2002, 21, 3108; (b) M. Ochiai, H. Hashimoto and H. Tobita, Angew. Chem., Int. Ed., 2007, 46, 8192; (c) M. Lipke and T. D. Tilley, J. Am. Chem. Soc., 2013, 135, 10298.

14 G. I. Nikonov, Adv. Organomet. Chem., 2005, 53, 217.

15 (a) L. J. Procopio, P. J. Carroll and D. H. Berry, J. Am. Chem. Soc., 1991, 113, 1870; (b) L. J. Procopio, P. J. Carroll and D. H. Berry, Polyhedron, 1995, 14, 45; (c) U. Burckhardt,
G. L. Casty, T. D. Tilley, T. W. Woo and U. Rothlisberger, Organometallics, 2000, 19, 3830; (d) Y. Chen, H. Song and C. Cui, Angew. Chem., Int. Ed., 2010, 49, 8958.

$16 \mathrm{Si}-\mathrm{H}$ couplings of $20-150 \mathrm{~Hz}$ are observed in silane $\sigma$-complexes and $\mathrm{Si}-\mathrm{H} \cdots \mathrm{M}$ agostic complexes: (a) Ref. 14; (b) Ref. 4.

17 O. G. Shirobokov, S. I. Gorelsky, R. Simionescu, L. G. Kuzmina and G. I. Nikonov, Chem. Commun., 2010, 7831.

18 (a) A. Y. Khalimon, S. K. Ignatov, R. Simionescu, L. G. Kuzmina, J. A. K. Howard and G. I. Nikonov, Inorg. Chem., 2012, 51, 754; (b) A. Y. Khalimon, S. K. Ignatov, A. I. Okhapkin, R. Simionescu, L. G. Kuzmina, J. A. K. Howard and G. I. Nikonov, Chem. - Eur. J., 2013, 19, 8573.

19 We believe that the apparently short $\mathrm{Si}(3)-\mathrm{H}$ distance stems from the low accuracy of finding protons by X-ray in heavy element environments.

20 D. H. Berry, J. Chey, H. S. Zipin and P. J. Carroll, Polyhedron, 1991, 10, 1189.

21 G. I. Nikonov, Angew. Chem., Int. Ed.., 2003, 42, 1335.

22 G. I. Nikonov, S. F. Vyboishchikov, L. G. Kuzmina and J. A. K. Howard, Chem. Commun., 2002, 568.

23 S. K. Ignatov, N. H. Rees, A. A. Merkoulov, S. R. Dubberley, A. G. Razuvaev, P. Mountford and G. I. Nikonov, Organometallics, 2008, 27, 5968.

24 An equivalent of free ethane is seen in the ${ }^{1} \mathrm{H}-\mathrm{NMR}$ spectrum $(\delta=0.92 \mathrm{ppm})$, suggesting that complex 5 may be formed via a metathesis between the ethyl group of complex 4 and free $\mathrm{PhSiH}_{3}$.

25 D. M. Heinekey, A. Lledos and J. M. Lluch, Chem. Soc. Rev., 2004, 33, 175.

26 J. Tomasi, B. Menucci and R. Cammi, Chem. Rev., 2005, 105, 2999.

27 G. J. Kubas, Metal Dihydrogen and $\sigma$-Bond Complexes, Kluwer Academic/Plenum, New York, 2001.

28 M. L. H. Green, P. C. Konidaris, P. Mountford and S. J. Simpos, J. Chem. Soc., Chem. Commun., 1992, 256.

29 P. W. Dyer, V. C. Gibson, J. A. K. Howard, B. Whittle and C. Wilson, Polyhedron, 1995, 14, 103.

30 M. J. Frisch, et al., Gaussian 03 (Revision D.01), Gaussian, Inc., Wallingford, CT, 2004.

31 (a) A. D. Becke, J. Chem. Phys., 1993, 98, 5648; (b) J. P. Perdew, K. Burke and Y. Wang, Phys. Rev. B: Condens. Matter, 1996, 54, 16533.

32 P. J. Hay and W. R. Wadt, J. Chem. Phys., 1985, 82, 299.

33 C. Gonzalez and H. B. Schlegel, J. Chem. Phys., 1989, 90, 2154.

34 SHELXTL-Plus, Release 5.10, Bruker AXS Inc., Madison, WI, 1997.

35 Olex-2 software: O. V. Dolomanov, L. J. Bourhis, R. J. Gildea, J. A. K. Howard and H. Puschmann, J. Appl. Crystallogr., 2009, 42, 339. 